\title{
La Novela Argentina desde 1950 a 1965
}

T SCribir acerca de los novelistas argentinos cuya producción ve la luz Lj durante los últimos quince años (a partir de I950, más o menos), es tarea que nos confronta con un doble riesgo: o çaer en el catálogo de nombres y hacer un trabajo que no tiene más mérito que el del inventario, o limitarnos a unos pocos nombres, con detrimento de otros que, por su calidad, por lo que nos dan o nos prometen, tienen todo el derecho a que se los estudie y haga conocer. Hacer clasificaciones es siempre una tarea falsa, pero no hacerlas conduce al caos. Como aspiramos a dar una visión integral (e integrada) de este período de la novelística argentina nuestro enfoque se hará, pues, desde diversos ángulos, y las divisiones que presentaremos, no deberán ser tomadas al pie de la letra.

En la actual novelística argentina coexisten varios estratos humanos en interacción. Hay una gran legión de escritores, muy conocidos, que atraen a diversos sectores del público y cuyas primeras obras datan del primer cuarto del siglo - o antes- pero que en estos años que nos ocupan continúan publicando sus novelas y gozando de cierta popularidad. Este es el caso de (por orden de edad): Enrique Larreta (I875-196I) con En la pampa, novela moderna (1955);1 Manuel Gálvez (I882-1962) con Las dos vidas del pobre Napoleón (1954), El uno y la mulditud (1955), Tránsito Guzmán (1956), Perdido en su noche (1958) y Me mataron entre todos (1962); E. Martínez Estrada (1895-1963) con Sábado de Gloria y Marta Riquelme (5956); P. Rojas Paz (1896-1956) con Mármoles bajo la lluvia (1954); L. Gudiño Krámer (1898) con Sin destino aparente (1959); J. Goyanarte (I901) con Lunes de carnawal (1952), La quemazón (1953) y Fin de semana (1955); E. L. Castro (1902) con

1 Se entiende que sólo mencionamos las novelas publicadas a partir de 1950. 
Campo arado (I953); Max Dickmann (I902) con Los babitantes de la noche (I953; Faja de Honor de la SADE) y El dinero no cree en Dios (1958); M. Peyrou (I902), autor de La nocbe repetida (1953), Las leye's del juego (I959) y Acto y ceniza (1963); V. Barbieri (1903I956) con su Desenlace de Endimión (I95I) y su novela póstuma El in. truso (1959); Carmen Gándara (I905?) con Los espejos (I95I); Norah Lange (I906), que escribe Personajes en la sala al comienzo de la década y Los dos retratos en 1956; Bernardo Verbitsky (I907) quien sigue auscultando lo social (en línea que prolonga las preocupaciones de Boedo) en Una pequeña familia (I95I), La esquina y Calles de tango (1953), Un noviazgo (1956), Villa Miseria también es América (1957), Vacaciones - novela breve- (I959) y Es difícil empezar a vivir (1963) $;^{2}$ Art uro Cerretani (1907) surge con El bruto (1944) y continúa con La brasa en la boca ( (958), La puerta del bosque (I960), Retrato del inocente (I96I) y La viaraza (I962); J. Gómez Bas (1907), quien después del éxito de Barrio gris (1948) produce Oro bajo (1956) y La comparsa (1965); J. M. Villarreal (I908) con Mi propia borca (1956); E. Anderson Imbert (I910) autor de Fuga (I951); M. Mujica Láinez (Igro) con Los ídolos (I953, Premio Alberto Gerchunoff), La casa (1954), Los viajeros (I955; Gran Premio de Honor de la SADE), Invitados en "El Paraíso" (Premio Nacional de r958) y sus dos "best sellers": Bomarzo (1962) y El uniconio (I965); Emesto Sábato (I9I I), quien publica su primera novela - El túnel-en 1948 y no reaparece hasta 1962 con Sobre béroes y tumbas, aunque las reediciones de aquélla son innúmeras en estos años; Luisa M. Levinson (I9Ir?) con La casa de los Felipes (I95I) y Conciertio en mi (I956); Roger Plá (I9I2) con El dueto (I95I), Pciño verde (I955) y Las brújulas muertas (I960); A. Bioy Casares (I9I4) con El sueño de los béroes (I954); Julio Cortázar (rgr4) veterano del cuento, lanza su primera novela, Los premios, en I960 y la segunda, Rayuela, en I963; S. Bullrich (I915) da Bodas de cristal (1952), Teléfono ocupado (I955), Mientras los demás vienen (1958), Un momento muy largo (I961), El bechicero (1962), Los burgueses ( 1964 ), Los salvadores de la patria (I965) y La creciente ( 1967 ) a más de Tres novelas. (I966), reedición de tres ya publicadas; E. Wernicke (I9I5) autor de La ribera (I955), Cbacareros (I957) y Los que. se van (1958), quien en I96r lanzó una nueva edición de su primera

2 Un autor que ha vuelto a concitar atención es Leopoldo Marechal (1898). A su Adán Bueniosayres (1948) se ha sumado El banquete de Severo Arcángelo (1967), con una ola de entusiasmo por parte de los más jóvenes y de revistas tales como Primera Plana, que le dedicó tres números. 
novela. A. Ponce de León (I9I7) llega a la novela desde el campo de la poesía y con La quinta gana el Primer Premio Emecé; Abelardo Arias (1918) de cuyo Alamos talados siguen apareciendo nuevas ediciones, confirma sus excelentes condiciones narrativas en El gran cobarde (x956); su actividad continuará luego con Minotauroamor y Limite de clase (1964); Hellen Ferro (r919) aporta Los Aestigos (1958) y El convento del Cristo de ha Humillación (I96I); M. A. Noel (r919) publica La balsa (1954) y La cbilena (I96r); Juan C. Ghiano (I920) entra en la novela con Memorias de la tierra escarlata (I954); Estela Canto (I920), una de las escritoras de obra más penetrante y humana que arranca en I945 con El muro de mámol y se continúa con El retrato y la imagen (I950), El visitante del crepuisculo (1953), El estanque (1956), La noche y el barro ( $196 \mathrm{I}$ ), intento de novela testimonial e Iscabel ents'e las plantas (1966).

Eduardo Mallea (I903) se mantiene todavía en primer plano con novelas plenas de humanidad y dinamismo: Los enemigos del alma (1950), La torre (I95 I, segunda parte de Las águilas), Chaves y La sala de espera (ambas de r953), Simbad (1957) y Posesion-novelas cortas(1958); a éstas hay que sumar las reediciones de Fiesta en noviembre, La babia del silencio, Todo verdor parrecerá más sus ensayos, contra los que arremeterá el grupo joven.

Como puede apreciarse en esta lista, los nombres de los novelistas cubren un área temporal que se extiende desde el último cuarto del siglo XIX (Larreta, I875) hasta I920. Las tendencias son diversas: unos (Goyanarte, Verbitsky) constituyen una línea marginal de ruptura con el vanguardismo; otros se dedican a la novela policial y fantástica (Bioy Casares, Peyrou); algunos son novelistas de la tierra (Castro), o de un intenso lirismo (Lange, Anderson Imbert), etc. Además, se unen en este grupo nombres de autores ya consagrados (Gálvez, Mallea) con los de otros, nacidos hacia r9ro, cuya popularidad es un poco más tardía. Siguen a los maestros (en líneas generales), pero con una intensa necesidad de cambio. Son "los discípulos" aventajados de los vanguardistas que empiezan a hacer sus primeras armas hacia 1940 y que hoy están dando sus obras más maduras. Un grupo heterogéneo en el que los nombres más descollantes son los de Sábato y Cortázar.

\section{LOS ENOJADOS}

Frente a estas dos promociones literarias surgirá, hacia I945, un grupo de jóvenes, quienes, enojados y violentos, se volverán contra los 
mayores, despreciándolos por su esteticismo y vaciedad, por su retórica. Son los marcados por el peronismo (hoy al filo de los cuarenta años), los que quieren dejar constancia de los hechos, los que aspiran a un rea. lismo total, aunque lo trasmitan de manera diferente.

A estos jóvenes los llamaremos "los enojados" porque así es como miran la realidad en que viven, con enojo. Sólo algunos de ellos son intensamente militantes en una tarea de revisionismo de su cultura. Por ello encontraremos sus nombres no sólo en el campo de la novela sino, principalmente, en el del ensayo. Daremos la nómina en orden alfabético y luego estudiaremos en particular a los que consideramos de mayor importancia y más característicos: Julio Ardiles Gray, Antonio Di Benedetto, Beatriz Guido, Juan José Manauta, Héctor A. Murena, Pedro G. Orgambide, Federico Peltzer, Andrés Rivera, Alberto Rodríguez h., David Viñas. Y con una o dos novelas: Rubén Benítez (Ladrones de luz, I959), Néstor Bondoni ( $L a$ boca sobre la tierra, I956); Jorge A. Capello ( $L a$ bermosa vida, 1961); Iverna Codina (La luna ba muerto, 1957 y Detrás del grito, Primer Premio Interamericano de Novela, Losada, I96r); Marco Denevi (Rosaura a las diez, 1955); Eduardo Dessein (Los comienzos, Su generación, 1956); Valentín Fernando (Desde esta came, 1952 y El limite, I958); Rafael Gallegos (Los barrios de Mauricio, 1958), Adolfo Jasca (Los tallos amargos, I955); Alicia Jurado (La cárcel y los bierros, 196I); José David Kohon (El negro círculo de la noche); Mario A: Lancelotti (El traficante y La casa de los afeites, I963); Anselmo Leoz (El inspector Verano, I957 y Los muchachos del lápiz, I960); Luis Mario Lozzia (Domingo sin fútbol, 1956 y Los grandes peces ciegos, 1965); Martha Lynch (La alfombra roja, I962 y Al vencedor, I965); Jorge Masciángioli (El profesor de inglés, I960 y El último piso); Carlos Mazzanti (El sustituto, I954); María Esther de Mignel (La bora undécima, I961); Elvira Orphée (Dos veranos, Uno, r96I); D. R. Oxley (Tierra arisca, 1955); A. Pérez Zelaschi (El terraplén, 1954); Luis Pico Estrada (Unos cuantos días); Syria Poletti (Gente conmigo, Linea de fuego, 1965); Carlos Prelooker (La noche y dos sombras, r95 I y Pasto seco, 1955); Daniel Rodríguez ( 6 tatarabuelos); Dalmiro Sáenz (Hay hambre dentro de tu pan y El pecado necesario, 1965); Osvaldo Seiguerman (Una bistoria sentimental, 1958); J. F. Solero (La culpa, 1956 y El dolor y el sueño); Susana Tasca (Laura por la voz, 1958 y Manchado de limpio, I965); Angel María Vargas (El hombre que olvidó las estrellas); Julio J. Vieyra (Un rostro agrio). ${ }^{3}$

3 A éstos habria que agregar los nombres de Rodolfo Falcioni, J. A. Floria- 
Como en una misma época y país los diversos estratos humanos no se yuxtaponen o suceden sino que se entrelazan, aún tendríamos que formar otro grupo con los escritores nacidos del 30 en adelante, entre los que descuellan Sara Gallardo, quien en Enero (I958), ha sabido dar testimonio de una realidad sin intentar mejorarla consiguiendo trasmitir con fuerza el drama de la soledad de su protagonista. Asimismo, Renato Pellegrini, quien compone dos novelas -Siranger (1957) y Asfalto (1964) - de muchachos adolescentes en los que el problema de la homosexualidad, del sexo vacilante, es el eje novelesco.*

Aclaremos que entre estos jóvenes hay rasgos que los unen, pero hay otros que los separan. Algo es evidente, sin embargo, y es que -en términos generales - responden a dos tendencias tradicionales en la literatura argentina: unos se suscriben a una literatura comprometida, de testimonio o denuncia - Viñas, Guido, Manauta, Solero, Rodríguez, Rivera- $y$ otros hacen una literatura que no es social aunque tampoco pueda tildársela de esteticista o formalista (salvo quizá en un caso): Ardiles Gray, Di Benedetto, Mazzanti, Denevi, Jasca. Aún en la tendencia comprometida cabe separar los novelistas de ciudad de los de la tierra como Manauta y Rodríguez. Hay otros, como Murena, que continúan con planteamientos metafísicos e intrahistóricos. Más adelante volveremos sobre este punto.

Lo que "los enojados" tiene de común es el haber despertado a la vida literaria con la segunda posguerra, bajo el influjo de Sartre y el existencialismo; comparten inquietudes semejantes - literarias, sociales, políticas - $y$ han sufrido la experiencia del peronismo. Difieren en las soluciones, en su manera de expresarse, en su actitud comprometida o no, en que unos son más "enojados" que otros.

Considerando en su totalidad a los escritores que nombramos al principio y a estos "enojados", vemos que todos conviven pero situados en diversos niveles temporales, $y$ si bien todos son actuales puesto que todos existen y actúan en este momento, sólo algunos de ellos son rigurosamente actuales: Los otros o ya han perdido su vigencia (en parte o totalmente) o están luchando por adquirirla. Hoy, los novelistas argen-

ni, G. Gori, Luis Justo, Félix Luna, Jorge A. Riestra, Mauricio Rosenthal, Rodolfo J. 'Walsh, etc.

\# El nombre que debe colocarse al frente de esta última promoción es el de Abelardo Castillo (1935). Su obra - en la narrativa y el teatro- es ya de volumen: El otro Judas (1959), 1er. Premio Gaceta Literaria; Las otras pucrtas (1961), Faja de Honor de la SADE y $1^{3}$ Recomendación II Congréso Hispanoanericano "Casa de las Américas"; Israfel (1963), Premio Internacional de Autores Dramáticos Latinoamericanos UNESCO y Cuentos crueles (1966). Es, asimismo, director de la revista $E l$ escarabajo de oro. 
tinos de mayor vigencia, son los de la llamada "generación del 40" -Cortázar, Sábato como los más representativos- y junto a ellos los que hemos llamado "los enojados" - Beatriz Guido, David Viñas, Héctor A. Murena, etc. 5

\section{I945 - PUnTo de PARTidA}

El punto de partida para el estudio de este grupo literario es el año I945. ${ }^{\circ}$ En sus comienzos casi nadie le prestó atención. En especial desde las filas de la generación del 25, no recibió sino absoluta indiferencia, total desprecio o no disimulado fastidio.

Hacia 1945 ingresa a la Facultad de Filosofía y Letras de Buenos Aires una pléyade de jóvenes ${ }^{7}$ que, en plena formación (no tenían mucho más de I7 a 20 años), reciben el impacto de la ascensión al poder de Perón. ${ }^{8}$ Obligados a no hablar de política, se vuelven sobre la literatura de "los padres"9 para hacer una completa revisión de ella a partir de cero - -según el título de una de sus revistas-m; cuestionan

5 E. Rodriguez Monegal habla de que "la realidad reconoce generaciones dominantes y generaciones complementarias" (El juicio de los parricidas. La nueva generación argentina y sus maestros. Buenos Aires, Deucalión 1956, p. 88). El grupo del 40 ó 41 , para él, sería el de los epígonos del 25 y, por ende, la generación complementaria, mientras que el grupo del 50 "...es el que asume la responsabilidad de plantar un nuevo sistema de vigencias" (Ibidem). Es verdad, pero no vemos al grupo del 40 como complementario. Si bien ellos no inauguraron ningún sistema, su influjo, en el plano literario exclusivamente, es más considerable que el de "los enojados" (Véase A. Roggiano, "Situación y tendencias de la nueva poesía argentina", Rev. Iber. de Bibl., XIII $\mathrm{N}^{\circ} 1$ (1963), pp. 3-29).

6 "Pero a partir de esa fecha [1945], o en sus alrededores, es posible señalar cómo lo individual va dejando poco a poco de serlo, y cómo los individuos van tomando conciencia, lentamente, de sí mismos y de la situación común" (Ismael Viñas, "La generación argentina de 1945". Comentario, Año V, N 18 (enero-marzo 1958, p. 42).

7 "En octubre de $1945 \ldots$ los estudiantes universitarios ocuparon las Facultades en un acto para el que se invocaron sobre todo razones académicas, pero de evidentes raíces y resonancias políticas. En ese momento se echó a rodar por primera vez la frase generación del 45. Diez años después, y para designat de algún modo global a los escritores más o menos ióvenes, volvió a pretender carácter oficial aquella designación, pero ahora circunscripta al campo de la literatura..." (Ismael Viñas, "La generación", p. 35).

8 "Después de la década infame, la década absurda. Se conmueven todas las bases sobre las que se levanta la realidad del pais y deben ser revisados totalmente los valores que sustentan nuestro ser como nación. La convulsión sirve para desmoronar los mitos falsos con que se disfrazan nuestros problemas y verdades, y quedan al descubierto las fuerzas esenciales y genuinas, en una forma instintiva o primaria, pero verdadera" (A. Vanasco. "Un nuevo frente de la novela argentina", Contemporánea, $2^{a}$ ép. (octubre 1957), p. 3).

19 Como éstos lo habían hecho, a su vez, con la generación anterior. 
el concepto de literatura, el de escritor y el de las relaciones del escritor con la sociedad. Y toda esta actitud revisionista no es sino el preludio de esa búsqueda del ser argentino o nacional que hay que ver como motor de la obra de creación de "los enojados". Se ha roto la continuir dad histórica, y para estos jóvenes intelectuales ha llegado la hora de la toma de conciencia con su realidad. ${ }^{10}$ Los vicjos estereotipos culturales ya no sirven para juzgar esa realidad que es enteramente nueva, distinta, inesperada. Es decir, las condiciones sociales y culturales diferentes hacían impostergable una nueva definición. Y aquí es donde hay que buscar la constante que une a todos "los enojados", que es la liquidación del pasado, el rechazo de "los padres", el parricidio, como ha dicho Emir Rodríguez Monegal.

Los más de "los enojados" pertenecían a la burguesía (porteños o aporteñados, descendientes de inmigrantes), posición social que los llevará a tener siempre (aunque traten de ocultarlo con mayor o menor éxito) un cierto sentimiento de culpa. Desde el año 43 esa clase -como así también la terrateniente- ve desarrollarse dos fuerzas opuestas, pero igualmente peligrosas: el proletariado y la burguesía industrial (los nuevos ricos). ¿Qué pasaba en la Argentina? Los jóvenes no lo sabían con seguridad, pero sentían hondamente el cambio por su mayor ilustración y sensibilidad perceptiva. Tenían que tratar de entender lo que estaban presenciando, y el punto de partida tenía por fuerza que ser lo de antes, los planteos de los mayores. Para algunos de ellos, los que venían de la clase trabajadora, la respuesta fue más fácil: había que tomar el camino del proletariado, es decir, del petonismo.

\section{El Peronismo}

A "los enojados" la época les impuso un problema: el del peronismo. Ese fenómeno de la segunda tiranía argentina cavó una zanja tan honda en la vida de la república, que ésta saltó hecha añicos. Había

10 "La presencia de nuestro país se nos impone ahora de un modo irremediable, brutal a veces, y de un modo que llega a oscurecer la realidad externa ...lo que aquí ocurre cobra importancia, es decir, seriedad, pero seriedad de veras, no estiramiento. Ya no ocurre que lo impontante es solamente lo que sucede en otro lado. Lo que aquí, en nuestro contorno sucede, es también importante y decisivo... la vida dentro del pais ha cobrado urgente dramatismo, reflejado en los hechos externos, pero procedente de sus más profundas estructuras. Lo que ahora pasa aquí, la vida que se mueve a nuestro alrededor es seria y definitiva, y nos compromete sin escapatoria" (Ismael Viñas, "La generación", pp. 40 y 41). (El subrayado es del alutor). 
que rehacer las fuerzas del país y buscar el camino de una solución. Quienes van a iniciar la reacción son, precisamente, los jóvenes enojados. Para ellos, el peronismo vino a actuar como un estimulante. Si bien el país venía dando tumbos desde los años 20 y la "década infame", quizá la oposición de "los enojados" no hubiera sido tan violenta de no haberse confrontado con una realidad tan absolutamente inesperada como la del régimen de Perón, que puso en la superficie tantas cosas. A nosotros nos dolía la Argentina en I945 con la misma intensidad que a los españoles del 98, España. Con el agravante de que nosotros no teníamos tradiciones en las cuales refugiarnos. Estábamos confrontados con una nada total.

El peronismo dejó su marca en todos: los peronistas y los antiperonistas. Por lo menos hubo que tomar posiciones y examinar - sincerándose- el por qué del fenómeno, los males que habían hecho posible tal explosión. Había que asumir el país "como fenómeno nacional". ${ }^{11}$

El peronismo es, pues, la experiencia compartida fundamental de todos estos jóvenes, es la que los acerca aunque sus objetivos difieran, es la que los une en el anatema contra los mayores. Esto explica la heterogeneidad del grupo, la disimilitud de su crítica, bien claramente polarizada en las dos revistas más representativas de la época: Contorno y Ciudad. Como solía decir David Viñas, "Si no fueta por Perón, andariamos a los tiros entre Contorno y Ciudad".

\section{LAS REVISTAS}

"Los enojados" querían decir cosas, tenían mucho que decir, pero ¿dónde publicar? Sur y La Nación eran (y todavía lo son, en parte), los bastiones olímpicos de "los padres". La alternativa era o sucumbir a ellos o crear nuevos órganos de expresión. Por esto último optaron "los enojados" para poder decir lo que sentían. Así nacen cantidad de revistas de vida efímera, pero que son los documentos a los que hay que recurrir para escuchar las primeras voces de los enojados argentinos. Allí está Letra y linea (1953), tevista de cultura contemporánea (4 números) dirigida por Aldo Pellegtini, que se impone la tarea de "... revisión y renovación del criterio estimativo frente a las obras de las generaciones anteriores". Revisan la obra de Arlt (exaltándola. Vanasco lo hará), la de Sábato, Mujica Láinez, Goyanarte, Bernárdez y Molinari; Polémica

11 "A nosotros (dice Ismael Viñas) lo social y lo nacional se nos impone, tumultuoso, caótico, informe, fluido, prepotente" ("La generación", p. 41). 
literaria (1956); Ventana Buenos Aires (1952), en la que se unen Mario De Lellis ("generación del 40") y Roberto Hurtado de Mendoza ("enojado") con un programa de enfrentamiento a las escuelas vanguardistas y de defensa de lo nacional; Gaceta literaria (I956), bajo la dirección de Pedro G. Orgambide y Roberto Hosne; ${ }^{12}$ Verbum, en cuyo No 90 , de r948 (el último), apareció el artículo que se señala como el comienzo de la actividad escrita de estos jóvenes: "El pecado original de América" de H. A. Murena; Centro (I95I) ${ }^{13}$ que comparte algunos de los redactores de Verbum, como Jitrik, pero muy distinta de aquélla. Un equipo capitaneado por los hermanos Viñas - Ismael y David-con gentes de Filosofía y Letras, da nacimiento a Contomo, indudablemente la revista de mayor resonancia, y la renovadora por excelencia. Aparece en las postrimerías del peronismo (1954), juntamente con Ciudad y, a pesar de que en ambas colabora casi la misma gente, son muy distintas. Los artículos de Contorno critican duramente a los mayores, pero con seriedad: son sustanciosos, polémicos, de preponderante visión sociafilosófica. Son antiperonistas, pero no al modo del hombre de la calle, sino en un sentido más profundo, más adulto y realista: el de aceptación de la culpa por los pecados que la engendraron y del subsiguiente castigo. ${ }^{\text {is }}$ Sus diez números son indispensables para conocer el pensa-

12 Orgambide habla de una "Liberación de la literatura" argentina en estos términos: "...esa literatura [la social] fue la que más certeramente expresó lo argentino. Del otro lado - de los sectores más retardatarios del país- surgió una literatura de expresión cosmopolita, cuyas últimas derivaciones son los héroes psicologistas, merodeadores de la existencia, siempte sometidos a sus autrcondenas y complejos de culpa... Quisieron... edificar una literatu a apátrida, despojada de los elementos reales de nuestra existencia como país. Traicionnon - conscientemente o no-.. su misión de intérpretes y creadores de un? literatura argentina" (Gaceta Literaria (febrero 1956), $\mathrm{N}^{\circ} 1$ ). (E1 subrayado es del autor).

13 Editorial al $N^{\circ}$ 9, julio de 1955, de Centro: "Los números de Centro han nacido de una inquietud, de una rebeldta, de un disconformismo con el ambiente universitario y su mediocridad" (p. 6). Y más adelante: "He aquí el balance. Expresión. Inquietud. Rebeldía. En todo caso, la plenitud de un testimonio. Tal vez no logremos cosas concretas. Tal vez nos reduzcamos a proyectos, y no sea esto tan poco. De todos modos, en nuestro ambiente, en que todo parece enquistado y cerrado, estamos tercamente dispuestos a seguir siendo pasibilidad" (Ibidem. El subrayado es de los editores).

1.4 En la Revista de Revistas de Centro ( ${ }^{\circ} 10$, nov. 1955), J. R. Latforgue se expresa así sobre Contorno: "...tiene sentido vital abonando su razón de existencia. A través de sus cinco números se palpa una misma inquietud, un mismo entusiasmo definido y serio, una misma pasión en el planteo de los problemas. de la literatura argentina. Se revisa y revaloriza lo dado de acuerdo a una posición-irrupción, y se señala, o quizá más, una salida superadora" (p. 122).

El $\mathrm{N}^{\circ} 2$ de Contorno se dedicó al análisis de R. Arlt, el 3 a la obra de V. Ocampo, M. Gálvez, Mallea y J. C. Onetti; el 4 a Martínez Estrada; el 5 y 6 a la novela argentina. Los números posteriores se ocuparon más bien de política: peronismo y frondizismo. 
miento de "los enojados". Ciudad, dirigida por Carlos M. Muñiz (que tendrá un alto cargo en el gobierno revolucionario de 1955), secundado por Adolfo Prieto, asume desde el principio una actitud conciliadora en lo que respecta a "los padres". Quiere competir con Sur y posee un matiz católico. Es únicamente revista literaria. ${ }^{15}$ Ambas intentan la revisión de los valores de la generación del 25, aunque limitándose siempre a tres nombres: Mallea, Borges, Martínez Estrada. Volveremos luego sobre esta revisión.

Mención aparte queremos hacer de Buenos Aires literaria, a cuyo nacimiento - en I952- asistimos muy de cerca. Fue una revista de mayor categoría cultural, ${ }^{16}$ pero en ella no se asumió la nueva pesadilla. Y aunque tangencialmente oponen reparos a los mayores, sus páginas están abiertas a todos los valores consagrados. No obstante, no se hallan incomunicados con "los enojados". Por ejemplo, César Fernández Moreno, uno de sus colaboradores, escribe un artículo revisionista sobre Borges para Ciudad en r955. Y Ramón Alcalde (de Contomo) envía colabo. raciones a Buenos Aires literarid. Estos entrecruzamientos son los que hacen difícil ver claro el panorama. Pero debe tenerse siempre en cuenta la contemporaneidad de los distintos grupos que anotamos y su interacción.

\section{CRítica y Ficción}

Arriba nos referimos a la actitud crítica, revisionista, de los valores del 25. Los "parricidas" de Rodríguez Monegal son esencialmente los críticos. ${ }^{17}$ Lo que se enjuicia es lo que los mayores han hecho, cómo lo

15 L. Sigal ofrece esta crítica de Ciudad: "Se ha quedado en el plano de la mera literatura como entretenimiento y adorno... no notamos el nucleamiento en torno a un elenco de problemas enfrentados por una misma actitud, sino solamente el propósito de hacer una revista y llenar sus páginas" ("Revista de Revistas", Centro, No 10 (noviembre 1955), p. 120). Y con respecto a los dos primeros números dedicados a Martínez Estrada y Borges, Sigal dice esto: "El tratamiento de los valores consagrados es sólo un medio para fijar, a partir de ellos, en disenso o asenso con ellos, la propia pasión... [estos] artículos... carecen de la toma de posición que les hubiese conferido sentido y permitido ver al través de sus obras un aspecto de la realidad argentina" (Ibidem, p. 120).

16 Entre sus redactores estaban Amado Alonso, los dos Romero, Enrique Anderson Imbert, Julio Cortázar, Daniel Devoto, Alberto M. Salas, etc.

17 "Los parricidas no somos más que un puñado: algunos de los que escribieton en el número 90 de Verbum; algunos de los que escribieron en la $1^{\text {a }}$ época de Centro; casi todos los que escribieron en Contorno; uno o dos de los que escribieron en Ciudad; más o menos una docena" (Ismael Viñas, "Algunas reflexiones en torno a las perspectivas de nuestra literatura". Ficción, $\mathrm{N}^{\circ} 15$ (setiembre-octubre 1958), pp. 8-9). 
han hecho y por qué. Al discutir, al negar - y muchas veces en ademán excesivo - la realidad que les había sido impuesta, estos jóvenes están dando la tónica de una nueva voz. No obstante, si se hubieran limitado a teorizar una renovación de valores y a demoler lo que estaba hecho, dando tan sólo un programa de futuras reconstrucciones, si se hubieran quedado varados en la teoría, no podríamos hoy hacer más que una crónica histórica de sus polémicas.18 Pero muchos de "los enojados" (fuesen o no parricidas) tradujeron al plano de la ficción las inquietudes que los consumían. Los nombres que dimos anteriormente son los de los novelistas. A algunos se los encontrará militando en ambos campos, como a Murena, Viñas, Solero. Pero hay otros que sólo fueron los teorizadores y críticos "enojados". He aquí sus nombres (por orden alfabético): Ramón Alcalde, Noé Jitrik, Rodolfo Kusch, Julio Mafud, Víctor Massuh, Héctor A. Murena, J. C. Portantiero, Adolfo Prieto, José A. Ramos, S. Rozitchner, Juan J. Sebreli, J. F. Solero, Ismael y David Viñas.

\section{Los Acusados y sus Crímenes}

Los escritores acusados por Cont"orno, en particular, eran "los padres", y de entre ellos, tres son los que atraen con más encarnizamiento a "los enojados": Mallea, Borges, Martínez Estrada. Pero hay diferencias en la crítica que se hace de ellos: a Mallea lo rechazan sin más trámite; Mallea está fuera de la época y de su problema. Borges divide a "los enojados" en borgianos fanáticos que todo lo alaban o en antiborgianos histéricos que todo le reprochan. Martínez Estrada despierta respeto, lo oyen y lo siguen, pero sólo en parte. Lo que "los enojados" reprochan a todos ellos - en líneas generales - es su exterioridad, su "a-genuidad" (palabra usada por Murena y tomada de Sartre). Los acusan de ser extranjerizantes, vacíamente idealistas y liberales insulsos, oligarcas (el gran insulto por aquellos años). A Mallea lo desprecian por frío e intelectual. Aceptan que su Historia de una pasión argentina implicó una denuncia, pero dicen que le falla "lo de adentro y las palabras"; 19 no

18 Ismael Viñas veía las siguientes etapas en el desarrollo de su grupo: 1) De 1945 a 1948: rompimiento limitado con la literatura conformista; 2) De 1948 a 1953, con centro de gravedad en 1950. El punto de partida es el $N^{\circ}$ 90 de Verbum (1948) con el famoso artículo de Murena "El pecado original de América"; 3) De 1953 en adelante, con centro en 1956, se encuentra todavía abierta (él escribía esto en 1958). ("La generación", p. 42).

19 Ismael Viñas, "La generación", p. 39. 
le perdonan la falsedad de esa división entre una Argentina visible y otra invisible cuando parecía no haber más que una sola Argentina y muy visible, por cierto. La panacea nacionalista que Mallea había postulado, le había llegado al país, sí, pero en una tealidad peronista, "descamisada", que era tan nacionalista como lo quería Mallea pero ¡de qué modo tan diferente! Murena, que inaguró esta revisión, podrá por lo tanto, llamar a Mallea "padre" pero "ajeno". ${ }^{20}$

El Borges atacado por "Ios enojados" es el de los cuentos fantásticos y laberínticos; un Borges que aborrece el nacionalismo, pero también un Borges con una obra de tal magnitud que la nueva gente tenía, necesariamente, que detenerse frente a él y meditarlo. Unos sucumben a su encanto (como ya dijimos) y se vuelven sus epígonos, aunque, por falta de genio, no pueden tocar sino la corteza del arte borgiano. Otros comienzan a negarlo sistemáticamente, aunque lo admiran (como se nota por el uso que hacen de sus expresiones más peculiares). Murena es otra vez el punto de partida de esta crítica (seguido por Ramos, Prieto, David Viñas, Portantiero), crítica que va a barajar juicios tales como eclecticismo, nihilismo, artificiosidad, extranjerismo, hedonismo, superficialidad, cosmopolitismo, bizantinismo, oligarca que cultiva géneros "muertos" y cuya obra es "prescindible", "proveedor literario" de la élite, traidor... Los epítetos podrían multiplicarse, como también la incomprensión y, en muchos casos, una total injusticia. Pero lo evidente en todas estas críticas es la "ajenidad" (otra palabra sartreana) de "los enojados" frente a la obra de Borges, a sus contenidos y técnicas, a sus valores. Adolfo Prieto lo expresó muy concisamente: "El joven de hoy no entabla polémica con hombres maduros que enseñorean política o arte, ni se ríe, ni se apasiona contra ellos; los observa, trata de comprendetlos porque forman parte de su contorno vital, pero íntimamente se siente desvinculado, ajeno, y se refugia en una completa indiferencia al mundo exterior o masculla casi siempre a solas los planes para su propio mundo futuro". 21

20 Vanasco es virulento y excesivo en su ataque. Dice así: "Un autor joven que por esos años parece estar dispuesto a sentar plaza de disconforme o a poner las cosas en su lugar, adquiere un fácil renombre hasta que desdice sus primeras protestas y toma partido al fin de cuentas por todos los vicios y deformaciones que en un primer momento parecía haber estado a punto de querer impugnar. Acepta puestos, fabrica incondicionales para su séquito y se deja arrastrar por el turbión. Antes y después, por desgraciai, lleva un mismo nombre: Eduardo Mallea" ("Un nuevo frente", p. 3). Rozitchner afirma que Mallea ha borrado su comunicación con el mundo, que es un puro que no puede comprender la sordidez; un burgués que se lamenta por el tiempo ido mejor que el actual. David Viñas achaca a Mallea su quictismo.

21 Borges y la nueva generación (Buenos Aires: Literatura Argentina; 1954). 
A Martínez Estrada se le considera el profeta, mas no se soporta su falta de esperanza. Su Radiografía de la pampa es una "Biblia del pesimismo", una "profecía del fracaso". 22 Se lo acusa porque ha adoptado una actitud de juez de la realidad, de quien está muy por encima de ella y la asume pero como predicador, como observador, sin ensuciarse mezclándose en esa realidad. Su influjo, sin embargo, es el más sostenido. Murena lo llama "conciencia de América", "sociólogo de la realidad argentina y americana", "ontólogo de la realidad americana". ${ }^{23}$

¿Cuál es el valor de este ataque a los hombres del 25? ¿Cómo debemos verlo? Parece indudable que al analizar a estos escritores, "los enojados" querían buscar lo que estaba vigente en la tradición literaria del país, querían fijar los límites de su realidad, esto es, dibujar su contorno vital. Por otra parte, injusta o no, su crítica supone una mirada dirigida desde una nueva perspectiva en el tiempo; es un nuevo punto de vista que está subrayado por ese sentido de ajenidad que mencionamos y que parece indicar la irreconciliable separación de estos dos núcleos. contemporáneos, la imposibilidad del diálogo entre ellos. ${ }^{24}$ Desde un ángulo estrictamente literario, hay que reconocer que la crítica de los enojados contra Mallea y Borges, particularmente, es menos literaria que filosófica, política y social. La pasión que pusieron en su tarea de examen es comprensible por la edad y la circunstancia; lo que ensucia ese impulso honesto y valedero es el tono con que se expresó, el insulto a

Vanasco asalta a Borges en este tono: "Un escritor fragmentario, de filiación preciosista, de perfeccionado e inoperante enfoque menor, empieza por aquel entonces a transformarse en el campeón del escapismo, en el primer espadachín de la irresponsabilidad: Jorge Luis Borges, que dará con su obra el tono literario de la década infiame. Un pequeño coro de aduladores profesionales y amorfos lo rodea y aprueba, unos pocos porque están en juego y los más por inconciencia" ("Un nuevo frente", p. 3).

iख2 A. Zum Felde, Indice ctitico de la literatura bispanoamericana. I. El ensayo y la crítica (México, Guarania, 1954), p. 474.

23 Ismael Viñas lo ve de este modo: "Martínez Estrada construirá en definitiva un dibujo de nuestro mundo local tan sin salidas, que terminará por ser la excusa de los mismos satisfechos a quienes cree denunciar y conmover. Pero se animará a frotar con sal todas las rendijas, con una curiosidad y una obstinación un poco depravada de chico y de progresista desilusionado" ("La generación", p. 39).

24, De este modo se expresa Ismael Viñas en el No 1 de Contorno: "Rebeldía, rechazo, desconcierto. Eso es lo que sentimos. El mundo, este mundo inmediato, nuestro país, nuestra ciudad, nos aprietan como algo de que somos responsables. . los hombres de letras nacidos hacia el 900 nos parecían dotados de una excesiva complacencia con el mundo, con las mutuas tareas, con el comportamiento colectivo... nos parecian demasiado complacidos en sus trabajos: o dedicados a la elaboración anecdótica del mundo como espectáculo melodramático, o planificados en un superficial esquema de denuncia, o demorados en una descripción terrorista y sin salidas". 
que se llegó en muchos casos o la mezquina defensa de intereses personales.

\section{AutOREs ACEPTADOS}

Entre los escritores aceptados y convertidos en pendones de lucha por "los enojados", figura en primer término Roberto Arlt, en quien vieron "...al buceador del alma humana en sus elementos más complejos".25 Le siguen en importancia Horacio Quiroga, Roberto J. Payró, Eugenio Cambacérès y Francisco Sicardi, adoptados porque en ellos ven lo auténtico argentino, el ser nacional sin embozos ni disfraces. Son escritores realistas (como pretenden serlo "los enojados") que denuncian los conflictos argentinos para que el lector reaccione, que interpretan la realidad que tienen a la vista y que, en verdad, han hecho una literatura tan comprometida como la que Sartre había enseñado a "los enojados". De ahí el rescate y la adopción que llevan a cabo.

\section{LNFLUJOS}

Señalaremos tres clases de influjos: a) los que vienen del campo filosófico, sociológico y político, particularmente, Hegel y Marx. Leyéndolos aprenden a esgrimir un lenguaje dialéctico y de tono filosófico; b) los filosófico-literarios; Sartre, sus obras y los artículos de Les Temps Modernes, Camus y el Merleau-Ponty de Les aventures de la dialectique alimentan sus ideas y los llevan a volcarse en el ensayo polémico y, especialmente, en la novela. El existencialismo francés les proporciona, pues, su pensamiento y su instrumento de expresión;26 c) los estrictamente literarios. Hay dos literaturas que los atraen por su no mitigado realismo, por su desembozado ataque a lo tradicional. Ellas son la norte-

25 Juan Carlos Ghiano, La novela argentina contemporánea (1940-1960). Buenos Aires, Dirección General de Relaciones Culturales. Ministerio de Relaciones Exteriores y Culto, s.a., p. 8.

$26 \mathrm{La}$ novela les resulta el género más adecuado porque, atenidos como están al principio sartreano de la literatura comprometida, ven en ella el "testigo.., juez.., cómplice.., espejo" del proceso de desarrollo de la sociedad moderna. Así se expresa Noé Jutrik en Seis novelistas argentinos de la nueva promoción (Mendoza: Biblioteca Pública Gral. San Martín, c. 1959), pp, 18-19. E Iverna Codina dice algo semejante: ". . la novela engendra los elementos -testimonia, rebeldía, denuncia, crítica- para una superación dialéctica de esa misma realidad" (América en la novela, Buenos Aires: Cruz del Sur, 1964, p. 200). 
americana - Hemingway, Steinbeck, Faulkner, Caldwell, Scott Fitzgerald- de la que imitarán el lenguaje directo y las técnicas -intersubjetividad, monólogo interior, simultaneísmo-. La otra literatura les vino de la vieja Italia que, en su segundo renacimiento a mediados de este siglo, produce pensadores y novelistas de la talla de Cesare Pavese, Antonio Gramsci (cuyas obras sólo se difundieron después de I95I), Carlo Coccioli, Alberto Moravia, Elio Vittorini, Guido Piovene, Vasco Prattolini extensamente leídos en la Argentina por estos jóvenes. Y junto a esa prosa, el otro influjo que marcó profundamente a "los enojados" argentinos fue el del cine neorrealista italiano y el francés.

Debemos consignar aquí que la literatura del propio continente no les interesa en demasía. Sólo últimamente se detendrán en un Fuentes, un Rulfo o un Vargas Llosa. Pero hacia el 50 los que se leían - y con alguna displicencia- eran icaza, Alegría, Gallegos, Asturias, Amado, Verissimo, por lo que, con respecto a estos autores no puede hablarse de un influjo propiamente dicho. Icaza, Arciles Arguedas, como Alegría en menor medida $y$, en general, la narrativa indigenista dará el molde a "los enojados" que hacen novela de la tierra como Rodríguez, por ejemplo. No obstante, su influencia es muy limitada. En general, los argentinos - estupendamente al día de lo que pasa en las letras europeas y norteamericanas - seguirán las corrientes que allá se dan aunque - como es ley en la literatura hispanoamericana- el ritmo será distinto.

\section{LA Novela}

Estos son los antecedentes que hay que tener en cuenta para acercarse a la ficción de "los enojados". Vayamos, pues, a esa novelística y tratemos de comprenderla. Dijimos antes que entre los escritores del 50 se notan dos tendencias: o son autores comprometidos que dan testimonio o denuncian los conflictos sociales, políticos y de explotación del hombre por el hombre, o hacen una literatura en que lo sicológico, el ser humano y sus problemas internos, es lo más importante. Sin embargo, si nos contentáramos con esta división estaríamos muy lejos de dar idea cabal de las tendencias que informan la novelística argentina del 50 en adelante. Tomemos, por ejemplo, los comprometidos: ya advertimos que dos de ellos hacen novela de la tierra - Manauta, Rodríguez- frente a los 
más con novelas de ciudad. Beatriz Guido comienza con los conflictos de la adolescencia y juventud ( $L a$ casa del ángel, $L a$ cáda) y sólo a partir de su tercera novela - Fin de fiesta- entra de lleno en el problema político argentino. Héctor A. Murena no pierde de vista lo que sucede en su país, es un testigo atento, pero lo que él hace (o pretende) es una novela de gravitación metafísica con descripción de la situación del hombre, de su relación con el universo, con la existencia, con la historia, consigo mismo. No obstante, en este grupo la necesidad de dar testimonio de una realidad (como veremos) es el común denominador de los novelistas, por encima de todos sus matices diferenciales.

Donde la tarea didáctica de clasificación se resiste más, es entre los. autores no comprometidos. Entendamos que todos, tanto en una como en otra tendencia, son neorrealistas, pero en los de este segundo grupo no se puede hablar sino de individualidades, de parcelación de la realidad humana o social: Ardiles Gray hace realismo mágico en páginas de un acentuado lirismo; Marco Denevi y Adolfo Jasca inventan relatos policiales a los que no es ajena la preocupación sicológica; Antonio Di Benedetto, en su afán de explicar al ser americano, revive la novela histórica y la llena dè símbolos, de poesía, de sugerencias o construye un "pentágono" amoroso que es un alarde de técnica novelística; Carlos Mazzanti se encierra en la mente de su "sustituto" y nos entrega sus dudas metafísicas, y así todos. Hacen novela sicológica, policial, realista, lírica, esteticista... Quizá nuestra proximidad temporal es el mayor estorbo para una sistematización; lo es también el hecho de que todos estos novelistas están en plena producción y en plena formación, se están buscando y esos tanteos implican casi siempre cambios, elecciones dispares. Hay, sin embargo, en este grupo un común denominador, tal como lo hallamos en el otro, y es el hecho de que todas estas novelas son existenciales. Expliquemos. La novela no es ya más esencialmente una historia (Mauriac, Martin du Gard) sino, por el contrario, es el medio que el escritor escoge para expresar $s u$ visión de las cosas, $s u$ verdad interior, sus mitos: es, pues, el equivalente de la confesión, del ensayo, del poema. Sus libros son sombríos, lúcidos y en ellos los protagonistas están constantemente indagándose $\mathrm{y}$, a través de ese buceo, tratan de trascender su medio y su momento en una búsqueda de valores universales. Son personajes ansiosos, sin guías, sin puntos de apoyo que deben hacer sus elecciones, que asumen su responsabilidad. Quizá sería por esto más propio hablar de un naturalismo metafísico que de existencialismo. En muchos de estos autores, además, esa metafísica surge 
del propio quehacer vital, no es libresca o basada en sistema filosófico alguno.

Hagamos un enfoque más de cerca de esta novelística. Caractericemos lo que cada uno ha dado $y$, a partir de ese análisis, tratemos de encontrar las constantes de esta narrativa, es decir, saquemos conclusiones aplicables a ella como un todo. ${ }^{27}$

DAIID VIÑAS (n. I929)

David Viñas es, a no dudarlo, el representante por excelencia de "los enojados", el autor de mayor popularidad entre los de este grupo y el de obra más numerosa: seis novelas, un libro de cuentos, ${ }^{28}$ y dos ensayos $^{29}$ son vigorosas muestras de su dedicación. La televisión ha ayudado mucho a difundir su imagen ( $y$ su poblado bigote de hombre enojado) como así también el hecho de que el popular director Fernando Ayala haya filmado dos de sus cuentos - El jefe (1958) y El candidato (1959) - y que de una de sus novelas - Dar la cara- se haya hecho una película dirigida por M. Suárez en 1963 .

Viñas es una figura discutida que, desde el día mismo de su ingreso a la Facultad de Filosofía y Letras de Buenos Aires, concitó más antipatías que afectos. Pero lo que no puede negársele es su vital entrega a las ideas que profesa; su misma rudeza es fruto de esa pasión y a ella hay que adscribir los defectos más graves de su novelística.

Viñas encarna mejor que cualquiera de sus coetáneos "enojados" esa actitud revisionista que hemos asignado al grupo. Sus obras son un vivo documento de ciertos momentos, de ciertos aspectos, de ciertos prototipos humanos de la vida argentina. Su novelística es totalmente comprometida (aún en los libros que no apuntan directamente a lo político o social, sino a lo humano). Lo literario como forma pura no le interesa. Lo primordial en él es su voluntad de realismo y de critica integral; su intención es terminar de una vez por todas con los mitos nacionales, con la imagen idealizada y convencional de su país, imagen recibida como herencia y forjada por los "padres" a despecho y en contra de

27 Los autores que analizamos -en la imposibilidad de pasar revista a todos los nombrados - son los que consideramos más representativos de las distintas tendencias dentro del grupo. Son también (salvo quizá uno) los de mayor nombradía y difusión.

28 Las malas costumbres (Buenos Aites: Jamcana, 1963).

29 Literaturd argentina y realidad politica (Buenos Aires: J. Alvarez, 1964). y Del apogeo de la oligarquia a la crisis de la ciudadi liberal: Laferrere. ${ }^{8}$ "ed. (Buenos Aires; J. Alvarez, 1965). 
la realidad que tenian frente a ellos. Por esto la rebeldía total de Viñas es, en verdad, un programa de liquidación de esa imagen incongruente y falsa. En este sentido, su obra tiene una proyección histórica y sociopolítica.

Viñas, desde sus años de Contorno hasta el presente, ha estado siempre tratando de asumir su contorno, pero ese afán suyo de no permanecer al margen, esa necesidad de ir dando el testimonio de ciertos negros capítulos de la vida argentina, se le imponen con mucha mayor fuerza que el quehacer literario en sí y entonces Viñas-novelista se desploma y se queda en Viñas-periodista 0 , a lo sumo en Viñas-teóricovuelto-novelista. Porque lo que le pasa a Viñas es lo que invalida: la obra de todos los que no separan los límites de la creación artística y la confunden con una ideología o con la sociología o la transforman en un libelo. Las novelas de Viñas carecen de una estructuración nacida desde adentro; él se propone una tesis como cosa previa y, de acuerdo a ella, va manejando situaciones, personajes, hechos. Todo está movido en función de la tesis que sustenta y que va a demostrar en las páginas de su novela. De ahí que sus personajes carezcan de emoción, que no estén nunca totalmente logrados, que no los pueda plantar frente al lector como verdaderas criaturas humanas. No hay uno solo que quede en nuestra memoria, que nos toque, que evoque una respuesta 'simpática'. Sus novelas carecen de ritmo sostenido porque, con frecuencia, largas afirmaciones de tipo teórico, importantes con respecto a la tesis, fracturan ese ritmo en forma caprichosa, de modo tal que el saldo que deja la lectura de la novelística de Viñas es de insatisfacción: hay garra, hay potencia creadora pero su peor enemigo es no sólo su naturaleza polémica, rabiosa sino el criterio con que novela, el compromiso que de ello hace.

En cuatro de sus novelas - Cayó sobre su rostro (1955), Los dueños de la tierra (I959), Dar la cara (1962) y En la semana trágica (I966)Viñas ha hecho la revisión de la época de Roca, de sus caudillos campesinos, de la apropiación de las tierras patagónicas a principios del siglo y la matanza de los indios, del idealismo y ceguera del Irigoyen anciano, de las luchas del obrero urbano en la semana trágica de I9I9 hasta desembocar en la atmósfera de la Argentina de I958, cuando "se hunden definitivamente - son sus palabras- las grandes y fáciles ilusiones". El autor ha compaginado estas novelas como una especie de gran fresco de la historia argentina desde después del 80 hasta el presente. Y aunque el retrato es desmesurado a veces, e interesado y parcial muchas, el esfuerzo ha sido hecho y vale la pena otorgarle nuestro interés. 
Cayó sobre su rostro30 inicia este ciclo de novelas histórico-políticosociales. Y ya en ella están las características generales a toda la novelística de Viñas anotadas antes, en especial su interés en demostrar ciertos hechos de la vida argentina: el "acomodo" y la venalidad de los políticos, el desprecio por los derechos de las gentes y su violación sistemática por el caudillo pueblerino, el rol de abyección a que se condenaba a la mujer. Aparece aquí otro elemento infaltable en Viñas: lo sexual visto como total animalidad en la que el caudillo se tevuelca hasta en su impotente vejez, lo que lo lleva a morir en el prostíbulo local.

Todos los personajes son violentos y primarios; Vera es el arqueh tipo del caudillo campesino y en ese nivel permanece aunque se le quiera dar una trascendencia humana. Para esto, Viñas construye su novela en dos planos que aparecen alternativamente y que se repiten a lo latgo de las 166 páginas del libro: El día del juicio y Los años, o sea, el plano histórico y el subjetivo, el del ser íntimo del caudillo. Dos planos contrapuntuales que señalan el influjo de Faulkner y de Huxley. Pero el realismo crudo y provocativo en que está labrada la novela, trae -más que nada - reminiscencias de Arlt, Cambacérès y Payró.

Los dueños de la tierra ${ }^{31}$ lleva como epígrafe una frase de Radiografía de la pampa de Martínez Estrada: "La tierra es la verdad definitiva, es la primera y la última: la muerte". Con lo que Viñas pareae apuntar su índice acusador a los que han desvirtuado esa tierra argentina, ensuciándola con los crímenes de su interminable voracidad. Viñas pinta ahora cómo se ganó la Patagonia, cómo se exterminó allí la "barbarie" india y cómo se estableció la "civilización" del más fuerte y del más bestial. Este racconto histórico abarca las tres primeras partes del libro: "I892", fin de la presidencia de Carlos Pellegrini y matanza de los indios patagónicos; "19r7" encuentra ya "dueños de la tierra" que se enriquecen vendiendo su lana a Inglaterra al abrigo de la primera guerra y "I920" es la crisis en la explotación de los obreros al paralizarse las exportaciones. Todo este relato está hecho en tercera persona utilizándose bastardilla. Señalamos ésta como una de las características formales de Viñas que él usa constante y sistemáticamente. Junto a este procedimiento subrayante Viñas usa también otras formas de relieve expresivo: el entrecomillado y el doble guión. ${ }^{32}$ En Cayó sobre su

30 Buenos Aires: J. Alvarez, 1964.

31 Buenos Aires: Eudeba, 1966.

32 Véase Raúl H. Castagnino, "Otros caminos de la estilística: las "formas de relieve" por vía tipográfica en la técnica de algunos novelistas argentinos contemporáneos". Humanidades (La Plata), XXXVI (1960), pp. 123-148. 
rostro el uso de las comillas, en particular, había sido desordenado, confuso y abusivo. Pero ya en esta otra novela (la cuarta cronológicamente) hay mayor sabiduría y cuidado aunque no siempre un criterio uniforme. La bastardilla de estas primeras partes de Los dueños les confiere unidad, son como una introducción preparatoria necesaria para arribar a lo nuclear de su novela. Y ya allí la bastardilla indicará o valores "tonodistintivos" de algunas palabras, o frases que el personaje lee, o los pensamientos del protagonista. La bastardilla se une frecuentemente al entrecomillado para destacar expresiones de otros personajes que el protagonista evoca. Más que el influjo de formas de relieve similares aprendidas en Faulkner Joyce, Kafka, etc., creemos ver en Viñas un afán extremo por destacar los diversos planos en que desarrolla su novela, a fin de que el lector no pierda ningún matiz, para que alcance la sutileza de sus desplazamientos y el sentido - o la intención - que hay detrás de cada una de las palabras que así se subrayan.

El resto de Los dueños se divide en otras tres partes: "La misión", esto es, la gestión de Vicente Vera por orden de Irigoyen, que llega a la Patagonia como árbitro entre peones y estancieros. Se trata de explicar a Vicente pero no se logra tal cosa. Vicente es un personaje indeciso, construido en escorzo, cínico a veces y otras apocado, tonto. La ingenuidad del Presidente como la de su enviado están muy impuestas, no surgen de los actos sino de la repetición - hasta el fin del libro- de las frases "Había que ser imparcial. El representaba a un gobierno imparcial, qué duda había..." "equidistançia, equidistancia", "hay que ser ecuánime". El "Intermedio" es amoroso y narra la relación entre Vicente y Yuda, la maestra judía librepensadora. Pero otra vez aquí uno no sabe qué pensar de la muchacha pues, aunque por momentos parece estar muy preocupada por el destino de los obreros, por las injusticias que les hacen, y aunque también parece odiar a los "señoritos" conservadores ${ }^{33}$ y sentirse muy judía, siempre hay como un desleimiento de sus acciones y ella no emerge con un perfil bien definido. "La expiación" es la amarga prueba del fracaso de Vera por la inhabilidad para comprender la red de intereses creados que sofocan las intenciones de un gobierno demasiado crédulo y decadente.

En Los años despiadddos y Un Dios cotidiano, Viñas se vuelve hacia la adolescencia y hacia su propia experiencia en una escuela religiosa.

33 Ver p. 126 y ss. 
Los años despiadados ${ }^{34}$ son los de un adolescente atrapado en la red de los convencionalismos e inhibiciones que su familia le ha tendido: "hay que hacer las cosas como Dios manda", "hay que tener miedo de las cosas". El chico está obsesionado con el hecho de que "los mayores hacen lo que quieren" y le disgusta sentir que él es "blando". Entiende que para liberarse de esa tutela tiene que endurecerse y, en efecto, la paliza que le propinan los chicos del barrio le abrirá las puertas de ese milagro que es la libertad recién descubierta. Pero sobre esta base temática; Viñas ha construido una serie de símbolos que trascienden la historia particular de Rubén y apuntan hacia lo nacional. Rubén es la clase media, pleno de inhibiciones, atado a una tradición que le es extraña (representada por las ropas viejas que la madre guarda en la casa), a conceptos artificiales, inválidos, pasados de moda. Mario, su amigo, el hijo del portero, por el contrario, representa el ser libre de las clases bajas, que actúa y hace sin prepararse para ello, sólo porque debe hacerlo o porque quiere. Es mal hablado y peronista y permite que los muchachos de su pandilla castiguen a Rubén, que lo insulten aunque luego se arrepienta de ello y vuelva a buscar el calor de la amistad del otro. Para él no hay tradiciones (sus padres son inmigrantes), no tiene otra cosa que sus dos manos y el futuro por delante. $\mathrm{Y}$ cuando estos dos chicos, finalmente, se unen para destruir todas esas antiguallas que la madre atesora, lo que consuman es la liquidación de las tradiciones, están liquidando el pasado familiar de igual modo que en las calles de Buenos Aires se comenzaba por aquel entonces (la acción parece desarrollarse en los primeros años del peronismo, quizá r946) a liquidar el pasado político argentino: "Romper todo, se dijo. Sería fácil liquidar todo eso. Viejo. Viejo y podrido... Todo viejo, pensó Rubén. Todo estaba liquidado: esas casas destruidas, esa calle. En realidad, toda la ciudad estaba así. Liquidada y achatándose bajo ese sol aceitoso" (pp. 202-203).

El libro se reciente por la demora en la acción que está estirada, dilatada; por ese detenerse en detalles materiales sin importancia que destruye el ritmo novelístico. La forma es machacona, repetitiva hasta llegar a la monotonía. Hay un uso excesivo, abusivo de lo obsceno, un regodeo en lo vulgar; ${ }^{35}$ de ahí que la novela ofrezca un muy sabroso repertorio de expresiones lunfardas y de palabras más o menos fronterizas como gambeta, geta, requintar, cargar pibe, rajar, biscui, cascar, micbiguen, pura parada, sonar, cui cuí, fajar, cusco, etc.

34 Buenos Aires: Letras Universitarias, 1956.

35 Véanse pp. $7,27,36,37,46,87,203$, etc. 
Otra caracteristica expresiva que es dable advertir en ésta y otras novelas de Viñas, es el elevado número de sus diminutivos en la mayora de los casos de un acusado valor peyorativo, como así también sus comparaciones metafóticas siempre desagradables que acentúan aspectos negativos de las cosas o personas.

En general, el lenguaje de Viñas es simple, directo, llano y también lo es su sintaxis. A veces, resulta excesivamente lato. Nos permitiremos señalar una costumbre que, por ser constantemente repetida y no obedecer a razones de claridad, afea la prosa de Viñas. Nos referimos al uso pleonástico del pronombre átono en casos en que el complemento está ya denotado por otro nombre al que aquél se refiere (lo que la gramática denomina doble acusativo o doble dativo). Los ejemplos en las novelas de Viñas se podrían multiplicar ad infinitum pues no hay página casi en que no aparezcan uno o más casos y siempre en situaciones en que el uso del pronombre sin más hubiera sido suficiente: ". . lo miró fijamente a Rubén..." (p. 35); "...la había visto a su madre..." (Ibidem); ". . se le acercó a su bermana..." (p. 39).

Un Dios cotidiano ${ }^{36}$ es una novela en gran medida autobiográfica (cuenta algunos aspectos de la vida de Viñas en un colegio salesiano), desplegada en la década del 30 , durante la guerra civil española. Aunque el título parezca sugerir un dilema religioso de conciencia, el problema está planteado más en términos de la ineficacia de la religión en un país dominado por políticos cínicos y prácticos.

El Padre Ferré y el Padre Porter son los protagonistas dialécticos que Viñas ha debido crear para desenvolver su polémica entre un lírico que ve los abismos pero aún conserva su fe y esperanza y un desilusionado que "tentía necesidad de envilecerse" (p. 2or) para que sus dudas no lo destruyeran. Ferré es, como dice Porter, un "hombre en estado puro... una abstracción" (p. 240), algo inexistente, imposible. $Y$ si bien el Dios que él ama es cotidiano porque se lo tiene que hacer cada día, es un dios vital y activo, Ferré confrontado con un dogma, con una sociedad, con un puñado de superiores y de reglas, lucha ineficazmente porque desconoce las leyes del juego y se olvida de la realidad azuzante, la desconoce, viviendo en un mundo platónico en busca de la verdad como de un moderno santo grial y "tirándoselas de santo", sin decidirse a nada.

Que esta es una novela de tesis lo prueban las repetidas conversaciones de los dos sacerdotes sobre religión, extremismo, la guerra civil

$36 \quad 2^{4}$ ed. Buenos Aires: Kraft, 1958. 
española, las ideas de Péguy, la música, etc. Son charlas de evidente propósito dialéctico pero vivas, interesantes, eruditas a veces, jugosas siempre. Una especie de contrapunto en que los participantes buscan sobresalir. Junto a esos islotes de esgrima mental, la narración de ciertos aspectos de la vida en el colegio, implica una necesidad de certificar bien claramente el proselitismo ridículo y abyecto a que se sujetan esos oídos jóvenes, la total falacia de una educación que los convierte en hipócritas desde muy temprano.

Dar la $\operatorname{car}^{37}$ es un libro casi naturalista. Empeñado como está Viñas en incluir su contorno en la acción novelesca, en exterminar ciertos tabúes de su sociedad, se detiene morosamente en circunstancias que no están justificadas ideologógica o novelísticamente, sino que comportan un sensacionalismo de mal cuño. Esos muchachos que salen del servicio militar y: que, provenientes de distintos estratos de la sociedad argentina, se enfrentan con problemas diversos, están tratados desordenadamente. Los conflictos que los agobian son innúmeros y esto diluye la credibilidad del personaje. Los seres que Viñas crea, los problemas - como el universitario- a pesar de su naturaleza polémica, son sombras de lo que pudieron ser. Todo queda en la superficie o se hunde - como es frecuente en Viñas - en un sexo enfermizo y en un oleaje de mucha mala palabra.

En la semana trágica la narración está trabajada en dos planos: uno novelístico propiamente dicho, con centro en Camilo, $y$ otro periodístico que relata las luchas de los obreros en la histórica semana de enero de I919. Las acciones de ambos planos son simultáneas y sirven de comentario mutuo. El libro está pobremente estructurado, es casi periodístico y parece haber sido escrito apresuradamente.

\section{BEATRIZ GuIDio (n. I924)}

La figura femenina más destacada del grupo "enojado", Beatriz Guido, ha levantado su fama en base a cuatro novelas y sus guiones cinematográficos, a más de una colección de cuentos. ${ }^{39} \mathrm{Ha}$ logrado alcanzar una popularidad considerable entre la masa de lectores, popularidad que obedece, en gran medida, a su labor para la pantalla y al hecho de estar casada con el director argentino de cine Leopoldo Torre Nilsson, laureado en Europa, conocido de los adherentes al bisoño festival de cine

37. Buenos Aires: Jamcana, 1962.

38 Buenos Aires: J. Alvanez, 1966.

39 La mano en la trampa (Buenos Aires: Losada, 1961). 
de Nueva York y ampliamente respetado en la Argentina. Circunstancias extraliterarias, pues, tienen mucho que ver con la difusión de la novelistica de Beatriz Guido.

Menos "enojada" que otros colegas de su promoción, ella trae a la ficción idéntica preocupación testimonial: fotografia la decadencia moral de la alta burguesía argentina, quiere mostrar su desintegración, su alienación con respecto al proceso histórico argentino. Beatriz Guido al desnudar ese estrato social, hace una crítica oblicua (al igual que David Viñas), documenta pero no of rece soluciones. Ventila las lacras de una clase social en un determinado momento del acontecer histórico, expone y nada más. Y en su pintura del ambiente social, de la atmósfera, hay alguna veracidad aunque con las limitaciones que señalaremos. Hay fuerza en las situaciones - a pesar de que casi siempre son muy primarias- no así en los personajes, muñecos movidos por hilos que son demasiado visibles y que no están manejados con total déstreza. Porque en Beatriz Guido, como en David Viñas, el crecimiento ha sido tan apresurado, la pasión que los lleva a crear estas ficciones testimoniales tan intensa, que no han tenido tiempo de madurar y la expresión se resiente por el esfuerzo de la composición. Luego tambiẻn en Beatriz Guido, como en Viñas, lo sexual es obsesivo y feo, desagradable. Hay en ella una especie de naturalismo de nuevo cuño que escarba las abyecciones humanas, aunque sin llegar muy abajo. $\mathrm{Y}$ todo inundado de un afán preciosista que resulta, frecuentemente, empalagoso, innecesario, excesivo y con el cual ella quiere acentuar ese decadentismo del mundillo de la aristocracia argentina.

En el aspecto formal, Beatriz Guido usa, mezclándolos, los procedimientos técnicos habituales de la novela moderna, pero más que un interés por la forma en sí creemos que hay un deseo de añadir una suette de especial complejidad a sus libros. Su lenguaje es "popular y vivo aunque con escándalo de la sintaxis", ${ }^{40}$ lo que suele afear, en particular, las descripciones. Quizá el mayor valor de esta novelista resida en su poderoso don inventivo; en la valentía de su propósito.

B. Guido podría ser considerada como la novelista de los adolescentes y sus crisis, sólo que junto a ello está la preocupación de índole nacional. La casa del ángel ${ }^{41}$ es la cárcel dorada de una adolescente en trance de volverse mujer. Su familia es rica, su padre un caudillo político, su madre una beata convencional. La acción transcurre desde 1925 y se

$40 \mathrm{~J}$. Blanco Amor en su reseña a La casa del ángel en Comentario, III, No 7 (1955), p. 84 .

41 Buenos Aires: Emecé, 1955. 
extiende por veinte años puesto que toda la novela es el racconto hecho por la protagonista desde su presente de mujer solitaria hacia zonas de su infancia y adolescencia pasadas. Todo el problema mental y síquico de la jovenzuela está descrito en términos que tratan de ser poéticos pero sólo logran resultar rebuscados. $Y$ se ha cargado tanto las tintas a fin de trasmitir la sensación de la exquisitez en que transcurran esas vidas, que resulta por momentos intolerable la acumulación de mojigatería en los actos y palabras de los personajes. Ana Castro, la adolescente, no convence a pesar de ser, junto con la madre, el personaje mejor perfilado. Sus mejores momentos son aquellos en que da libre paso a su imaginación y nos hace partícipes de sus sueños y extrañas visiones. Es que Beatriz Guido, como Ana, es superlativamente imaginativa. La vieja sirvienta Nana, llena de supersticiones religiosas y no muy educada, usa palabras demasiado cultas como mórbida (p. 36) o sabe de la existencia del KuKux-Klan (p. 67); el chofer del taxi se dirige a la señora llamándola madame (p. rog) lo que es insólito; por doquier el rebuscamiento en la expresión es la regla. Es decir, la autora se apoya en todo lo accesorio e inanimado para crear la atmósfera, de modo tal que ésta aparece impuesta, artificial.

En La caida ${ }^{42}$ Beatriz Guido se mantiene fiel a su estilo y al sector social que la preocupa, con acentuación del enfoque emocional de ese cuadro "costumbrista", y en general, supera su experiencia anterior. Albertina - la protagonista - una muchachita recién llegada a Bs. As. para matricularse en la Facultad de Filosofía y Letras, va a vivir a la casa de una familia de seres inverosímiles que han conocido tiempos mejores: una madre enferma en manos de cuatro criaturas diabólicas y de un tío siempre ausente pero cuya personalidad llena la casa y las mentes de los chicos con su mágico influjo. Cuando por fin él aparece, sobrevendrá un amor que asusta a la muchacha y del que huirá para no ceder. Lo mejor de la novela son los cuatro niños, verdaderos "enfants terribles", precoces, malignos, con un humor negro que, en ocasiones, es un tanto excesivo pero vivos, vivientes.

Albertina es, como Ana en la novela anterior, romántica e imaginativa, dulce y confundida. La pintura del ambiente de la Facultad, a pesar de algunos personajes estereotipados, es adecuada. Lo político está rozado apenas con el personaje de Indarregui que quiere "salvarse solo" en un mundo sin ideologias liberales.

La novela está escrita en tercera persona, con abundante uso de

$422^{a}$ ed. Buenos Aires: Losada, 1959. Fue llevada a la pantalla con idéntico nombre. 
diálogos directos y matizados y con continuo desplazamiento del tiempo, lo que a veces dificulta la lectura.

Fin de fiest $t^{3}$ es, sin duda, lo mejor de la producción de Beatriz Guido, y junto con El incendio y las visperas, 44 representa una meritoria tentativa de recrear la etapa político-social argentina que se inicia en el 30 y se extiende hasta los años anteriores a la caída de Perón, aunque coexisten los habituales conflictos adolescentes.

En Fin de fiesta hay interés en transmitir un clima nacional (el del 30 al 45), unas ciertas figuras típicas de la política argentina (algunas de las cuales son fácilmente reconocibles); la autora demuestra haberse documentado e indagado y querer ser verosímil aunque esté dando una versión novelesca de hechos reales.

El fin de fiesta a que alude el título es el comienzo de la era peronista y, en consecuencia, el desplome de la oligarquía caducante, de la que el caudillo bonaerense de Beatriz Guido es una de las figuras más características. Mas el interés de la novelista por los jóvenes, tiene ocasión de manifestarse nuevamente en la figura de los nietos del caudillo y en la profunda huella que éste deja en ellos. El Riachuelo, límite del dominio de Braceras y comienzo de la capital, de Buenos Aires, tiene valor de símbolo y parecería separar la "civilización" de la "barbarie".

Técnicamente, Beatriz Guido usa el narrador-protagonista ( $x^{a}$ pers.) y el omnisciente $\left(3^{a}\right)$ y también los desplazamientos temporales. Ha cuidado más su expresión y es posible aislar varias interesantes imágenes metafóricas. Lo sexual se da en los personajes con insistencia obsesiva y siempre, y con cualquier motivo, aparece el sexo como su fuerza caracterizadora y determinadora de su conducta. La simbología de Beatriz Guido - -en ésta como en otras novelas - es excesivamente directa.

El incendio y las visperas continúa el testimonio de la decadencia de la alta burguesía argentina, con el distinguido señor Pradere que claudica ante los peronistas, aceptando un cargo diplomático, a cambio de mantener intocada su estancia. La acción comienza el I $7_{7}$ de octubre de I952 y culmina en el incendio del Jockey Club, el I $_{5}$ de abril de 1953. La desintegración moral de la familia Pradere, el heroismo de Pablo Alcobendas, la lucha en contra del peronismo, la brutalidad policial, el amor, el sexo, todo está en este libro, pero muy hecho, muy forzado. Y siempre todo se halla rodeado de objetos exquisitos: camineros de Esmirna, la "Diana Cazadora" del Bernini, la bata de "Acuescutum" de

$433^{3}$ ed. Buenos Aires: Losadda, 1965.

$442^{a}$ ed. Buenos Aires: Losada, 1965. 
Londres, los tapices orientales, la colección de incunables, el perfume masculino Golden Medal, una bañera labrada en mármol de Carrara, los macetones con reproducciones de Della Robbia, la tetera pompeyana, el Thibon de Lebian del período azul, la "loggia", el "concerto" de Cimarosa, las "croissants", los candelabros de Capo-di-Monte, etc., etc.

\section{ANDRÉs RIVERA (n. I924)}

Este autor hace en $E l$ Precio (su primera novela) ${ }^{45}$ una literatura de compromiso político, documentando -en el marco de una fábrica textil- las primeras luchas de ese gremio y las de los metalúrgicos en I953. La acción se extiende desde 1943 a I953, aproximadamente. Se presencian las disputas en el seno de los sindicatos, la confrontación de algunos con el peronismo, las huelgas en contra de los patrones. $\mathrm{Y}$ junto a ello, lo personal, lo individual, las apetencias sexuales primerizas de hombres y mujeres.

Rivera ha intentado una pintura total, de fresco, de diversos tipos. argentinos: el obreto peronista, el indiferente, el comunista, el estudiante proletario, el patrón extranjero, el patrón argentino aristocrático y conservador, pero es este esfuezo tan ambicioso el que mutila los valores del libro porque la realidad se presenta excesivamente fragmentada $y$ confusa. Hay que conocer las alternativas de la historia sociopolítica argentina de esos años, para orientarse en la maraña de gentes y acaeceres.

Además $E l$ precio es libro de difícil lectura por el abigarramiento de procedimientos y técnicas estilísticas que el autor no maneja con total destreza. Uno de los factores que desorientan al lector es el uso, de formas de relieve expresivo por medio de variada tipografía: la utilización de bastardilla, entrecomillado, guiones y paréntesis es anárquica frecuentemente y difícil de captar la razón por la que se usan. El plan de la composición, asimismo, es complejo, con tres partes subdivididas unas veces de acuerdo a la acción, otras al personaje, otras a una secuencia cronológica particular -años, horas. Tan pronto se está fuera como dentro del personaje y, con frecuencia, cuesta comprender de quién se trata. El procedimiento simultáneo que se usa es también responsable, en buena medida, por la confusión en que se sume al lector.

Pero, a pesar de todo esto, Rivera denota talento en las enumeraciones caóticas de sus monólogos interiores, en el uso sistemático de la

45 Buenos Aires: Platina, 1957. 
repetición para alcanzar un clímax, en la lengua realista de sus personajes humildes (aunque se regodea un tanto en lo feo) y en sus metáforas poéticas que son como un oasis en medio de mucha violencia. En sus obreros hay verismo, en cambio falla en el retrato del patrón aristocrático que resulta un estereotipo.

Lo:s que no mueren $4^{46}$ es de factura muy semejante a la anterior novela pero en dimensiones reducidas. La idea central es la de la lucha inacabable del obrero por justicia y por más dilatados horizontes, no importa quién esté en el gobierno. La industria textil y sus gentes vuelven otra vez a vivir en sus páginas, en episodios que tienen lugar hacia x955. Y aun cuando la cronología es menos movible que en la primera novela, todavía hay desplazamientos que nos llevan hasta I935, I945 y 1949.

El libro está dividido en cuatro capítulos cada uno de los cuales se abre en dos direcciones:47 una que se centra en el obrero Carlos y está escrita en primera persona y la otra en su amigo Demetrio, en tercera persona. Al polarizarse toda la acción y el interés novelesco en estos dos personajes, la novela resulta escuálida por comparación con la anterior. Igual criterio simplificador ha aplicado Rivera a procedimientos y técnicas, y la novela ha ganado así en claridad. También ha moderado el uso de diferentes formas tipográficas y cuando echa mano de ellas, lo hace con mucha más lógica y sistema.

La repetición y las enumeraciones polisindéticas siguen siendo características del estilo de Rivera, como así también las imágenes metafóricas en las descripciones y la presencia constante de Bs. As. cuyas calles, barrios, parques parecen participar de los estados de ánimo de los protagonistas.

Juan José ManaUta (n. I919)

Allberto Rodríguez, h. (n. I920)

Como ya lo indicáramos, estos dos autores hacen "novela de la tierra" de tono social, de realismo a lo Icaza y, tal como Vanasco lo afir$\mathrm{ma}^{48}$ uno y otro constituyen "la extrema izquierda de una novela comprometida".

46 Buenos Aires: Nueva Expresión, 1959.

47 A excepción del último que se divide en cuatro.

48 "Un nuevo frente", p. 7. 
Manauta ha producido tres novelas: Los aventados,49 Las tierras blancas $^{50}$ y Papá José, ${ }^{51}$ todas localizadas en la provincia natal del autor, Entre Ríos.

En todas la temática es semejante: el éxodo del campesino entrerriano a la ciudad empujado por el despojo a que lo somete el terrateniente, por la transformación de los medios de producción, por la baja de los precios de los productos agropecuarios y, en el fondo, el terruño actuando como fuerza telúrica indisputable a la que el hombre responde con amor.

Pero en esta novela telúrica hay un elemento que le confiere una jerarquía artística de que otros ejemplos del género han carecido: hay una acusada preocupación formal, un lenguaje cuidado, una prosa correcta, hasta bella, de momentos líricos, tensa y vigorosa, capaz de emocionar.

En Las tierras blancas (y luego en Papá José será igual) la acción está desarrollada en dos planos contrapuntales: el del niño - el hoy-y el de la madre - el ayer-, planos que desembocarán juntos en el desenlace trágico en que lo social desata el odio y una amarga desesperación. Odiseo, el niño, es uno de esos personajes punzantes, imborrables, y se destaca de entre un conjunto de otros no muy bien construidos y excesivamente simbólicos.

El sectarismo de Manauta es lo que ahoga, frecuentemente, su hondura novelística.

Alberto Rodríguez, es mendocino y en sus dos novelas la acción transcurre en el antiguo dominio de los indios huarpes en Mendoza. Matar la tierrajiz es lo que quiere el inmigtante español para quien la tierra es un ángel vengador que le quita todo. $Y$ ello porque la tierra $y$ el indio son una sola cosa, y al matar al indio y apoderarse de su tierra, Justo ha firmado su sentencia. Esa es una tierra animizada a la que él tortura, hiere, hace sufrir lentamente y a la que intenta matar privándola de agua para vengarse de su propio sufrir. Una tierra "afiebrada" que "chupa ávidamente", con "chupones desesperados", la poca agua con que Justo la martiriza. Una tierra que "sangra" y "sufre", que se "convulsiona moribunda" con "espasmos agónicos" pero también una tierra que se enrosca en los cuerpos y los devora "implacable",

49 Buenos Aires: Doble P, 1952.

50 Buenos Aires: Doble P, 1956.

51 Buenos Aires: Doble P, 1959.

52 Buenos Aires: Lautara, 1956. 
"silenciosa", "indiferente", "enigmática". Es un duelo trágico en que el hombre conoce de antemano que será vencido.

El estilo es cortado, nervioso, lleno de metáforas -algunas muy. bien logradas- y de un vocabulario indígena que demanda un glosario. En los diálogos de los personajes indígenas, se usa bastardilla para poner de relieve las voces indias y su especial fonética.

En Rodríguez hay una brutalidad excesiva, lo que bien podría calificarse de tremendismo, en particular en lo que hace a la figura del indio. Algo muy semejante a Icaza. Carga excesivamente las tintas. En la región de las lagunas de Guanacache de su segunda novela - Donde baya Dios -53 que poco a poco se secan sin que el gobierno se inmute, las gentes se convierten en animales feroces sin fe, sin esperanza, desoladas bestias cuya brutalidad espeluzna.

Con sus novelas, Rodríguez quiere evidenciar el despojo de que se ha hecho - y aún se hace - víctimas a los indios. Está implícitamente poniendo en tela de juicio toda la política "civilzadora" de Alberdi y Sarmiento hasta Roca. Pero esto para él es tarea impostergable: los argentinos tienen que saber quiénes son, cómo son. Tiene que encontrar y mostrar el drama, la dimensión interior del criollo.54

PEDRo G. ORGAMBIDE (n. I929)

A principios de 1956 Pedro G. Orgambide funda Gaceta Literaria y en una breve nota de aquel número inicial - "Liberación de la literatura"- sostiene la existencia de una literatura social en la Argentina que, aunque imperfecta, es "la que más certeramente expresa lo argentino". Abomina la literatura de expresión cosmopolita anacional pues considera que ella niega "el papel dinámico de la literatura y de la vida" y es el "más descarnado retrato de nuestro colonialismo culturah". Cuatro años más tarde, en el No 20 de I960, en entrega especial dedicada a la literatura argentina, concretará los cargos en un estudio acerca de Borges sosteniendo que sólo por casualidad Borges es argentino. Una casualidad como tener un apellido o un prócer en la familia o pasear por una sala vacía. Está, pues, en la línea de los "parricidas" y con este nacionalismo y un concepto de la literatura como testimonio de lo que es la Argentina y América y de lo que debe ser, tratando de actualizar y completar la cultura argentina, se lanza a su obra ficcional.

53 Buenos Aires: Lautaro, 1959.

54 Reportaje en Gaceta Literaria, Na 1 (febrero 1956). 
La lista de su producción es considerable si se piensa en su edad y en que la atención de otras tareas le consume gran parte de su tiempo Orgambide es a la vez novelista, ensayista, cuentista y autor teatral. ${ }^{55} \mathrm{~A}$ los diecinueve años había publicado una Mitología de la adolescencia (Bs. As., I948) a la que siguió un ensayo "en simpatía", Horakio Quiroga, El bombre y su obra.56 Tres años más tarde se aventura en la novelística con El encuentro. 57

Es esta una novela de conflictos de seres pero de seres arrojadcsi por el destino a una realidad que no siempre fue la suya: Laura, Aldo, Enrique constituyen una familia errante, venida a menos, que debe enfrentar nuevas circunstancias en una nación de cambios violentos y totales. Todo es simple: la trama, los personajes y sus idiosincracias, el lenguaje con que las gentes se expresan. Orgambide no quiere hacer literatura y refrena un lirismo que, sin embargo, se le escapa a veces en bellas metáforas. Peto la buscada simplicidad del tono, la sordina que el autor le ha impuesto, la lentitud del ritmo novelesco, esos personajes que dicen poco, roban al libro emoción, fuerza y cuando se lo acaba de leer se lo siente no completamente logrado. Se aprecia calidad en el esfuerzo pero resulta un tanto desmayado.

Con Las hermanas58 - "nouvelle"- Orgambide ha avanzado gran trecho, por la penetración sicológica en sus personajes, por la soltura en la descripción de los provincianos que llegan a la gran ciudad y sus esfuerzos por subsistir en ella, por el manejo preciso de un diálogo ágil, verdadero. Hace un realismo con reminiscencias de Arlt.

Pero setá el próximo libro el que develará todas las posibilidades de Orgambide-novelista. Nos referimos a Memorias de un bombre de bien, ${ }^{59}$ una de las novelas más deliciosas publicadas últimamente. Son las memorias de "un hombre de bien" argentino, esto es, de un pillo que, a los sesenta años, recrea sus "buenos tiempos" pasados, a la manera del pícaro español tradicional. Y paralelamente a los pecados del hombre se despliegan los del país: las revoluciones, el fraude, el "acomodo", la hipocresía política, los negociados, el machismo, la década infame, etc., etc. La ironía juguetona, el humorismo logrado con recursos nobles, y una prosa cuidada que imita verazmente la novela picaresca no sólo en

55. Cuentos: Historias cotidianas y fantásticas (Buenos Aires: Alvarez, 1965). Teatro: La vida prestada, La buena familia, Concierto para saballero solo (Buenos Aires: Stilcograf, 1963).

56 Buenos Aires: Stilcograf, 1954.

57 Buenos Aires: Stilcograf, 1957.

58 Buenos Aires: Goyanarte, 1959.

59 Buenos Aires: Falbo, 1964. 
el tono sino también en el plan de composición, en la construcción del personaje y de sus andanzas es lo que más debe elogiarse en esta novela. Orgambide dedica su libro a Payró y Fray Mocho y, en verdad, a ellos nos recuerda este desenfadado pero, a veces, patético itinerario picaresco argentino. Orgambide llama a la Argentina "pais enfermo de solemnidad" y lo es por cierto; mas lo curioso es que él, que pertenece a una promoción de escritores "enfermos de trascendencia", ${ }^{0}$ haya sabido sacudirse esa actitud y hacer una radiografía de su contorno que fustiga, que desnuda pero con una sonrisa. Por un momento Orgambide se ha olvidado de que es un 'enojado' y ha cambiado la tónica dominante en la nóvela —oscura, violenta, pesimista- para llevarnos a una isla de humorismo.

En El páramorl se vuelve hacia el sur argentino pero aunque muestra la miseria y superstición de los mestizos, la estrechez mental de los europeos allí afincados, aunque habla del "país enfermo" y de la indiferencia del gobierno, la caracterización de tipo social se pierde ante la de los conflictos sicológicos de los personajes. Y la Patagonia es más un telón de fondo contra el que los seres arrastran sus existencias frustradas.

\section{Héctor A. Murena (n. I924)}

Su labor ha sido incesante desde 1946 y pone de manifiesto su capacidad creadora. Cuenta en su haber con no menos de catorce títulos en cinco géneros diferentes: poesía, ${ }^{62}$ teatro, ${ }^{63}$ cuento, ${ }^{64}$ ensayo ${ }^{65}$ y una trilogía novelística - Historia de un día- de la que nos ocuparemos. Clato que para hacer un estudio a fondo de la obra de Murena, habría que enfocarlo en su doble aspecto de novelista y de ensayista. No disponemos aqui de espacio ni tal es nuestro propósito. Sólo queremos señalar que la novelística de Murena se atiene a una problemática que él plantea y discute en sus ensayos, punto de partida de su labor ficcional.

60 Ver Rodríguez Monegal, op. cit, p. .22.

61 Buenos Aires: Dávalos y Hernández, 1965.

62 La viáa nueva (Buenos Aires: Sudamericana, 1951); El circulo de los paraísos (Buenos Aires: Sur, 1958); El escárdalo y el fuego (Buenos Aires: Sudamericana, 1959); Relámpago de la duración (Buenos Aires: Losada, 1962); El demonio de la armonía (Buenos Aires: Sur, 1964).

63 El juez (Buenos Aires: Sudamericana, 1953).

64 Primer testamento (Buenos Aires: Américalee, 1946).

65 El pecado original de América (Buenos Aires: Sur, 1954); Homo atomicus, $2^{\mathrm{a}}$ ed. (Buenos Aires: Sur, 1963); Ensayos sobre subversión (Buenos Aires: Sur, 1962). 
Murena - como lo dijimos antes - fue el que inició la revisión de "los enojados" con su artículo sobre Borges y la poesía del 25 (Sur, I948) y con el ensayo "El pecado original de América", aparecido en el № 90 de Verbum. Se transformó así en el pensador por excelencia de la promoción, y aunque más tarde sus coetáneos lo han rechazado'ó porque se volcó en las filas de Sur y La Nación, no puede olvidarse que él comenzó el sacudimiento y que él fue el punto de arranque en la crítica a Borges, a Mallea, a Martínez Estrada oponiéndoles un bien articulado sistema de pensamiento.

Murena lleva a su novelística su enojo con la realidad, con todo lo que lo rodea y si bien hay en él una percepción bien clara de esa realidad no hay interés fotográfico sino un sentido trascendente, una indagación de corte metafísico acerca del mundo en que vive y de la posición del hombre en él, del fatalismo que oculta un dios al que Murena no define con claridad. Sus personajes son seres angustiados pero en algunos de ellos aún alienta una esperanza.

Los individuos de Murena son pasivos, hablan poco, padecen en silencio, están sujetos a un fatalismo lógico del que no pueden librarse. No están ubicados socialmente, son entes solitarios que se desenvuelven en el tiempo y el espacio. Y por ello entra en la trilogía de Murena el acaecer argentino, el peronismo, la agitación política como concesión a esas coordenadas temporal y espacial. Pero no se mete en el problema, lo roza; la relación entre lo que pasa en el país y los conflictos de sus personajes, es epidérmica; son referencias circunstanciales que no hacen a la esencia de la trama novelesca, recurrentes pero difusas. $\mathrm{Y}$ casi siempre esos hechos políticos que se cruzan en la acción, están actuados por masas brutales, cínicas e impúdicas.

Murena escribe fríamente, sin colores aunque con fluidez. La narración ocupa el mayor lugar y está manejada por un autor omnisciente. Los diálogos son breves, de palabras cortas y sirven como de puentes a largas disquisiciones seudo filosóficas que más se acercan a las expresión ensayística que a los pensamientos silenciosos de seres humanos. Los personajes tienen contadas oportunidades para expresarse directamente. Murena no se los permite; se interpone siempre entre sus criaturas y prefiere relatar un hecho o una conversación a ponernos en directo contacto con ellos. Esto unido a una floja caracterización del ambiente (aun-

66. Como dice Rodriguez Monegal: "De adalid y casi fuhrer de su generación, Murena ha pasado a ser ahora un poeta aislado, hermético e incomunicado" (op. cit., p. 97). 
que se nota el esfuerzo por lograrla) disminuyen la eficacia y la emoción de la novelística de Murena.

Sabe crear situaciones pero las crea en número excesivo y entonces no nos permite comprender a sus personajes ni sus vicisitudes. Las criaturas de Murena son demasiado intelectuales y compuestas, silenciosas, perdidas en el fárrago de palabras con que el todopoderoso autor nos las envuelve y en la cantidad de cosas que les suceden.

Las tres novelas están emparentadas por medio de su protagonista: Elsa, personaje secundario de La fatalidad de los cuerpos es la figura central de Las leyes de la noche y lo mismo sucede con Clotide de Los berederos de la promesa. Es decir, hay una identidad conceptual con la que se han redactado las diversas unidades temáticas de la trilogía.

En la primera novela, La fatalidad, ${ }^{67}$ la extraña enfermedad que abate al hombre de acción que es Alejandro Sertia, le propone una serie de interrogantes metafísicos "¿Quién, cómo, por qué?. El pobre planeta. La desnuda Tierra... Está [el hombre] desde que abre los ojos hasta que los cierra, abocado a Dios o a la Nada. Por eso, quiéralo o no, el murmullo de su sangre y de sus ideas, de su acción y de su pasión, repite siempre, medroso o con valor, siempre: ¿Quién, cómo, por qué?" (pp. I 28 a 130) Extensas reflexiones de este tipo están hechas usando cláusulas de largos encadenamientos hipotácticos, por lo general, o paratácticos a veces, que dificultan la lectura, que la vuelven tediosa y que, sobre todo, destruyen el ritmo novelesco y la continuidad del conflicto.

La destrucción final súbita del protagonista en esta novela, prueba esa "fatalidad de los cuerpos" del título y la tesis del atuor: "[todo indicaba] al fin que la salud no había querido decir vida ni la enfermedad muerte, que el supuesto pecado no había sido agravante, ni la supuesta virtud atenuante; [se moría] por decreto, sin explicación, por la desnuda espalda..." (p. 249).

En Lall leyes de la noche68 Elsa -centro de la narración en $3^{\mathrm{a}}$ persona -es protagonista perseguida por un destino implacable del que - según ella - no puede defenderse. Su vida se asienta sobre un vacío que termina por poseer a los seres humanos y contra el que es en vano luchar. Sin embargo, el vacío no engulle a Elsa porque cuando se arroja a él "...no había hallado un demonio, sino una enorme mano invisible que la había recogido, la había hecho flotar..." (p. 264). Porque finalmente Elsa se ha dado cuenta de que el vacío en realidad no existe, sino

$67^{\circ}$ Buenos Aires: Sur, 1955.

$682^{3}$ ed. Buenos Aires: Sur, 1963. 
cuando se lo lleva dentro y que hay que vivir sin temor, saliendo al encuentro de las cosas.

Elsa es una protagonista gris, abúlica, dada a reflexiones seudo metafísicas que resultan bastante infantiles. Mientras que de los otros personajes se nos dan descripciones físicas, de ella se dice muy poco. El autor se mete dentro de la muchacha y desde alli relata sus peripecias; Elsa camina mucho por un Buenos Aires que corre unido a sus estados de ánimo y habla poco porque el autor sigue amordazando a sus personajes y hasta los diálogos nos son relatados en muchos casos, tal como en la novela anterior. No hay comunicación entre Elsa y los otros personajes ya que todos parecen metidos en túneles de vidrio que recuerdan a Juan Pablo Castel. $\mathrm{Y}$ además, Elsa tiene un grave conflicto sexual que Murena pone de manifiesto en una serie de sueños que introducen un erotismo chocante, brutal, que salta de las páginas del libro como una pedrada. Habría que hacer un estudio sicoanalítico de este elemento onírico en Murena y de la significación de los animales como símbolos de lo sexual.

El estilo es un poco menos pesado que el del libro anterior. Especialmente en los cinco primeros capítulos: hay más frases breves, directas, simples. Y a pesar de que luego vuelve a la sintaxis más complicada que ya le conocíamos, comparado con el de La fatalidad, el ritmo de esta segunda novela resulta más ágil, aunque todavía se pueda hablar de monotonía.

En la tercera novela de su trilogía, Los beredero's de la promesa, ${ }^{69}$ hay un mayor acercamiento al clima político de las postrimerías del peronismo. Mas lo que preocupa a Murena es la alienación de Juan de su contorno, su hermetismo frente a una sociedad y a una atmósfera cultural que tiende a la apatía, al conformismo. Por ello Juan problematiza constantemente la relación con su contorno, por ello se aparta de ese que debiera ser su mundo y se refugia en un amargo sarcasmo, como único medio de preservar su libertad y no caer en la aceptación de lo establecido.

El gran cambio formal que acusa Murena aquí es el haber abandonado su tercera persona y haberse convertido en narrador-protagonista lo que aligera considerablemente su expresión.

69 Buenos Aires: Sur, 1965. 


\section{Carles Mazzanti (n. I926)}

Entre estas novelas de tendencia metafísica hay que reservar un lugar especial y aparte para la de Carlos Mazzanti. Y ello por dos razones: porque aunque coetáneo de todos los autores que venimos tratando, Mazzanti está completamente desvinculado de ellos. Es un solitario que crea apartado y cuya postura es personal y de carácter metafísico. Mazzanti parte de una concepción del ser y de la vida que ha formado en contacto consigo mismo mucho más que con los libros. $Y$ si sus ideas son compartidas o si su enfoque es más auténtico o válido que el de otro, poco le interesa. Lo que sí le importa es el hombre como elemento humano y social.

La otra razón por la que hay que detenerse frente a él, es la alta calidad de su obra que, no obstante, ha sido poco difundida en la Argentina.

Mazzanti ha llevado a su novela $E l$ sustinutoto una muy segura concepción del hombre y la vida, hasta el punto de que se puede hablar de una síntesis total de su metafísica con su expresión novelística. ${ }^{71}$

Hay en Mazzanti una preocupación ecuménica que lo lleva, en su novelar, a trascender las fronteras de su país. De ahí que no haya en $E l$ sustituto indicación exacta del lugar en que transcurre la acción: una playa, una estancia, un cuarto en la ciudad (en una ciudad innominada), una casita suburbana (un suburbio cualquiera de esa ciudad sin rostro), una cárcel, un café. De ahí también que su protagonista sea anónimo y que todo lo relate, en $3^{\text {a }}$ persona, un autor omnisciente.

Cuando se abre por primera vez $E$ l sustituto sorprende comprobar que es una novela escrita en un solo bloque, en una sola tirada, sin capítulos, sin blancos que inviten al descanso. No hay sino un párrafo único que se extiende, que fluye sería mejor, por I 36 páginas de tipografía pequeña y de flacos márgenes. Pero esa densidad formal tiene su razón de ser. El hombre, para Mazzanti, es una incansable máquina pensante que transita esclavizado por la infinitud de sus pensamientos, de sus imágenes, de sus ideas, de sus recuerdos. $Y$ ese acoso de su mente le crea una inbabilidad para actuar que debe superar si quiere subsanar

To $2^{\text {a }}$ ed. Buenos Aires: Instituto de Amigos del Libro Argentino, 1957. Otras obras del autor: La comisión de mentiras, La piel oscura, Paralaje 66 (teatro) y algunos cuentos. Cuando este artículo se habia ya preparado para publicación, nos llegó su $2^{n}$ novela, La cordillera del viento (Buenos Aires: Falbo, 1966). No hemos tenido tiempo aún de leerla.

71 Las ideas an que Mazzanti sustenta su novelística me fueron explicadas por él en una entrevista que sostuvimos en julio de 1966. 
uno de los graves problemas humanos. Es decir, que la escritura en bloque - de largas oraciones subordinadas- refleja ese fluir incesante de la mente, que jamás se detiene si no es con la muerte (con la cual acaba, precisamente, el libro). Pero el hombre transita, de donde los movimientos del protagonista a lo largo de las doce horas de un dia que cubre el libro. Transita cumpliendo las tareas mecánicas de levantarse, salir, desayunarse, sentarse en una plaza o en un café, ir a la cárcel, volver a su casa, etc., etc. $Y$ mientras transita lo acosan recuerdos, o sea, salta muy atrás en el tiempo y atisbamos su niñez, sus padres, vuelve al presente, se retrotrae a un pasado más próximo y entonces conocemos a su mujer, a su amante o, en otro desplazamiento, al pasado lejano, asistimos a la relación con su amiguita de la infancia y conocemos así los sentimientos que a estos seres lo ligaron. Hay hermosas imágenes de la playa, las plantas, el crepúsculo y el mar y hay, al mismo tiempo, expresión de las ideas que a lo largo de su vivir lo han acechado: qué es la angustia, la dicha, el dolor, Dios, el hombre, la existencia, la nada, el valor del tiempo - el presente asediado y destruido por el futuro. Ideas para muchas de las cuales no tiene respuesta y que quedan dudosas, enigmáticas, colgando de un quizá o de las numerosas oraciones interrogativas con que esas dubitaciones son expresadas. Ideas que no le dan paz, que lo torturan porque él, el protagonista, el hombre, vive su vida pero con un sentimiento cósmico, asumiendo el dolor de todos los otros seres. $\mathrm{Y}$ además en su mente, todo ese día, un pensamiento vuelve inquietante: el hombre joven', su vecino, que hoy morirá acusado de un crimen que -él está seguro- el pobre no ha cometido. Este pensamiento será el que lo empujará a romper su imposibilidad de actuar ya que sustituyendo al 'hombre joven' en el castigo dará sentido a su vida porque ". .él comprendía por fin que la hermandad entre los hombres sólo podía edificarse con acciones... [haciendo] cosas magníficas capaces de despertar en el individuo el cabal conocimiento de haber logrado el verdadero y único sentido de la vida" (p. r34).

Es, pues, evidente la relación entre contenido y forma, entre lo metafísico y lo novelístico.72 $\mathrm{Y}$ aún nos quedaría por llamar la atención, en esta novela tan densa, sobre una serie de notas: el amor por la naturaleza que Mazzanti evidencia, amor hecho de observación y de intima comunión de ser solitario; las metáforas poéticas muy cuidadas y cons-

72 Véase el estudio del Prof. Claude L. Hulet, "El sustituto: interpretación filosófico-literaria", Atened, XL, CXLIX (enero-marzo 1963), N 399, pp. 97-119. También U. Leo, "Vida, caridad, existencia. Meditaciones filológicas sobre un libro nuevo", RevIl, XXIII (julio-diciembre 1958), N 46, pp. 417-432. 
cientemente buscadas; la visión pesimista de la vida; el sexo como indispensable pero secundario; los símbolos innumetables; el tono evidentemente autobiográfico en algunos pasajes; el uso de un crimen como centro de interés novelesco, como llave para poner a prueba la capacidad del individuo en su búsqueda de la verdad (" $\mathrm{El}$ era un hombre! Un hombre que trataba de comprender", p. 77).

Esto último nos lleva a los influjos que Mazzanti acusa en su novela. El único que él acepta y reconoce es el de Dostoievsky. El parecido entre el introvertido protagonista de El sustituto y el de Crimen y castigo, es obvio, como lo es también la elección, en ambos autores, de un crimen como nudo de la acción. Pero la novela de Mazzanti tiene un halo poético muy especial y un amor por los seres minúsculos de la creación, que no hay en el escritor ruso. También se habla del existencialismo de Mazzanti aunque él confiese que, si bien había leído a Camus (L'êtranger) no tenía noticias de Sartre y que, por otra parte, no es proclive a limitarse a sistemas, sean ellos filosóficos o religiosos.

Novela primeriza y de juventud (aunque su autor afirma que no la cambiaría hoy), El sustituto es una cumbre aislada y orgullosa que promete una figura literaria independiente y de talento excepcional.

\section{Antonio Di Benedetto (n. I922)}

Otro autor que viene a sumarse a la distinguida nómina de los que narran a la sombra de los Andes mendocinos, Antonio Di Benedetto es un caso de excepción y unó de los mejores valores de esta promoción.

Como casi todos los otros, hace no sólo novela sino también cuento $\mathrm{y}$, como veremos, hasta los combina en un solo género. $\mathrm{Y}$ en ambos lo que debe subrayarse es su originalidad y un balance entre forma y contenido del que carecen sus coetáneos preocupados como están con sus denun. cias o testimonios. No así en Di Benedetto que tiene, obviamente, algo que decir pero que cuida como lo dice.

El nombre del autor mendocino se menciona, casi siempre, junto al de la novela objetivista, asignándosele primacía con respecto a la obra de Robbe-Grillet.73 Pero ese objetivismo -o literatura experimental, como

$73 \mathrm{El}$ cuento en que $\mathrm{Di}$ Benedetto hace objetivismo es El abandono y la pasividad, escrito en 1956 y no publicado hasta 1958 (edición bilingüe -castellano.inglés-, Mendoza: Biblioteca Pública San Martín). Les gommes, primera novela de Robbe-Grillet, apareció en 1954. De modo que cuando se afirma que Di Benedetto se adelantó a la "anti-novela" francesa, habría que precisar más las fechas o aclarar si el autor mendocino desconocía la novela del francés cuando compuso la suya. 
quiere Di Benedetto y nos parece más justo-, lo ha desenvuelto en sus cuentos, particularmente $E l$ abandono y la pasividad y en su "nouvelle" Declinación y ángel, 74 aunque ésta implica un procedimiento diferente. ${ }^{75}$ En sus dos novelas más importantes, hay otras preocupaciones de orden formal conjugadas a un contenido rico, sugerente.

Anterior a esos experimentos objetivistas es $E l$ pentágono,76 "novela en forma de cuentos" (como explica el subtítulo), compleja y desconcertante expresión en que se mezclan la realidad y el misterio, lo dramático y lo irónico con un resultado sumamente original.

En la línea temática, Di Benedetto parecería haber querido mostrar el proceso mental humano desde diversos ángulos o etapas temporales: de ahí los tres planos en que se divide su relato: el especulativo, el crítico y el real. Pero hay más que eso: los dos triángulos amorosos que, superpuestos, resultan en un pentágono de lo que el amor es y de lo que idealmente debiera ser, con esa Laura que "no está porque no es" y que "es aquello a lo cual se tiende" (p. I43) tal como la Dulcinea quijotesca, con la diferencia de que la amada renacentista "estaba" porque su amante la veía tal como la quería, y esta otra del siglo xx no está; con ese protagonista (muy kafkiano) perdido en la uniformidad niveladora de la vida oficinesca al que sólo distingue de los otros su amor; con esa incomunicación en su romance y con esa preocupación por la muerte.

En lo formal, el libro usa procedimientos y técnicas diversas -un tanto excesivas - y su estructura es compleja no sólo por la dislocación de la temporalidad sino por los cambiantes puntos de vista que asume el escritor. Habría que hacer un estudio estilístico detenido para desbrozar ese bosque. No es este nuestro propósito ahora, pero sí el llamar la atención sobre algunas características expresivas que, aunque atenuadas, se pueden hallar asimismo en las páginas de la segunda novela. Di Benedetto gusta de desenvolver su pensamiento en forma de juegos de palabras al modo barroco - cieclaró sin declatármela; señor sedente, señor ce-

74 Edición bilingüe -castellano-inglés-. Mendoza: Biblioteca Pública San Martín, 1958.

75 El lo ha explicado así en la edición de 1958: "El abandono y la pasividad está compuesto sólo can cosas, pero no simulándoles vida y lenguaje como en las fábulas. El florero es florero y la carta carta. Si el vidrio y el agua hacen estragos es en función meramente pasiva.

El drama humano se halla implícito.

Declinación y ángel está narrada exclusivamente con imágenes visuales —no literarias- y sonidos.

Fue concebido de modo de que cada acción pueda ser fotografiada o dibujada o en todo caso termine de explicarse con el diálogo, el ruido de los cbjetos o, simplemente, la música".

76 Buenos Aires: Doble P, 1955. 
dente; tan poco soy pero tampoco soy; angustiante angustid; angistiada angustia- y el aglutinar en una palabra dos significados esenciales, creando asi una síntesis total que traduce exactamente su pensamiento - frío metalfrio, calor carnecaliente, películas ayudasueños.77 Hay, demás, una gran cantidad de diminutivos en Di Benedetto de valor afectivo o sarcástico. La repetición y la suspensión junto con la prosopopeya, completarían el cuadro general de estos elementos de estilo.

En Zama $a^{78}$ su autor ha simplificado la técnica y los procedimientos $y$ ha ahondado en los problemas internos de su protagonista, confiriendo, no obstante, a su novela un dinamismo cinematográfico que -como $\mathrm{Di}$ Benedetto lo ha dicho- le pone "alas a la novela interior".

Zama es una novela histórica - se desarrolla en el siglo XviI de 1790 a 1799 - relatada por el mismo protagonista quien entrega las peripecias de su vida y de su espíritu, en un perdido rincón del continente americano. Don Diego de Zama, pacificador de indios, corregidor, asesor, es, en la novela de Di Benedetto, un héroe pequeño y frágil, cambiante, inconsecuente, descabellado, irresoluto, fanfarrón, débil, un hombre real en suma. Un pobre ser humano apresado por su época y circunstancias, por su desarraigo, por un sexo con demandas constantes y una sociedad que le impone como natural una castidad que él no puede sentir. Un pobre hombre angustiado que se enfrenta con su vida y con su muerte y que se busca y que no sabe adónde va porque ni él llega a los otros ni éstos a él. O sea, Zama es un hombre que comparte una actitud totalmente contempotánea nuestra y existencial. Pero Zama es también un desarraigado, que quiere marcharse, que vive en medio de un continente invisible, de un "paraíso desolado" que sólo existe en sus necesidades, temores y deseos y que lo somete contra su voluntad. Es a esa alienación entre el hombre y su América a lo que apunta $\mathrm{Di}$ Benedetto. Y para ello ha reconstruido el pasado, para buscar en él el ser verdadero del hombre americano.

La novela es bella e inquietante. Hay mucho elemento onírico y fantástico, misterioso y simbólico (el niño rubio, las mujeres veladas, los barcos-correos); hay un lirismo suave condensado en poéticas metáforas, todo hecho con sobriedad y justeza, con pulcritud aunque con intensidad.

El silenciero,79 la última novela de Di Benedetto, es un libro desconcertante, que intriga y atrae. Con ese protagonista que paulatinamente

77 Una variante serían las palabras compuestas, de este tipo: voz-llanto; intermedio primavera-invierno; parque-ciudad; miradas-bostezos; voz-susutro, etc.

78 Buenos Aires: Doble P, 1956.

79 Buenos Aires: Troquel, 1964. 
va enloqueciendo con los ruidos a que lo somete la vida ciudadana, Di Benedetto ha creado un punzante y kafkiano cuadro del hombre moderno.

Julio Ardiles Gray (n. I922)

Elegia, La grieta (ambas de I952), Los amigos lejanos y Los médanos ciegos (1956), El inocente (1964), son los títulos en el haber de este autor. En sus cuatro primeras novelas, Ardiles Gray muestra su interés por los niños y su proclividad por lo poético. Es tucumano y en la florida y templada provincia argentina ubica sus novelas, llenas de un lirismo sobrio, parco, como con sordina. Poeta que había sido premiado por la SADE en I948, aunque ignorado por el público, A. Gray llevará la vena poética a su narrativa $y$, con ello, en ocasiones, su mayor defecto ya que ciertos hiatos poéticos excesivos interfieren en el ritmo novelesco.

Elegíd es una "nouvelle" narrada en primera persona por una niña de once años. Es su diario. El autor y el narrador, pues, se aúnan y como todo se ve desde la mente de la niña, todo es simple, sin complicaciones. Es la recreación del mito de Peter Pan, del niño que no quiso ser hombre pero es también una "elegía" al niño que ya no somos. Enderezando el estilo a ser una lamentación, el autor habla en tonos apagados, en silencios, en una lengua casi sin color, extremadamente sencilla. Consigue rodear a sus dos protagonistas - la niña y el muchachito- de un halo poético, de una inocencia muy emotiva. Usa hermosas y poéticas imágenes. Pero A. Gray olvida frecuentemente que es una niña de once años quien escribe y pone en su boca observaciones, descripciones, frases que resultan incongruentes, que rompen el escudo creado por la primera persona y dejan al descubierto al autor. Más que una novela plenamente lograda es un ejercicio que promete mucho. En La grieta los reparos son parecidos y el tono similar al de Elegía. Se trata ahora de un muchachito en comunicación con la naturaleza y con lo más íntimo de los seres humanos que teme la inutilidad de sus esfuerzos. Esta novela forma ciclo con las dos siguientes - Los amigos lejanos y Los médanos ciegos_ 81 y todas prosiguen ese acercamiento al adolescente en su búsqueda de una explicación de lo que es el mundo y de lo que es él. A. Gray se apartará de esta modalidad tan sólo en la última de sus novelas, El inocente. ${ }^{\text {. No }}$ obstante, a pesar de que esta novela supone una incursión en el problema

80 Tucumán: Jano, 1952.

81 Buenos Aires: Doble P, 1956.

82 Buenos Aires: Seijas y Goyanarte, 1964. 
social - los trabajadores migratorios santiagueños que van a la zafra tucumana-y en el género policial, que allí cabe poner la segunda parte del libro, el título parecería destacar una idea central que mucho tiene que hacer con la adolescencia: la idea del gauchito que por primera vez abandona su querencia, que por primera vez presencia una huelga y sus violencias y que, por primera y última vez, se ve mezclado en un robo muriendo como víctima de una serie de circunstancias que lo aprisionan y despedazan. Se había enfrentado desnudo con el mundo y su inocencia no lo había salvado. La novela resulta confusa y la conexión entre las dos partes en que se divide, está dada fragmentatiamente por el personaje; no hay continuidad de tema o de ambiente. Si intentó hacer protesta social no lo logró enteramente pues todo queda a medias. Se detiene en detalles de vestimenta, de pintura de un determinado lugar pero falla en la construcción de sus personajes. Narra en tercera persona adoptando el punto de vista del autor omnisciente, y usa como procedimientos estilísticos la narración, la descripción, el diálogo directo y el matizado. Hay intento de hacer simultaneísmo en algunos pasajes pero, en general, A. Gray no es autor preocupado excesivamente por lo formal.

\section{Marco Dennevi (n. I922). Adolfo JASCA (n. I92I)}

Unimos estos dos nombres por cuanto las novelas de ambos participan, en medida semejante, de lo policial y lo sicológico.

Rosaura a las diez, ${ }^{83}$ del primero de los citados, no es una gran novela pero sí un libro bien estructurado y bien escrito. Si hubiéramos de escoger una o dos palabras para calificarlo, aduciríamos ingeniosidad y don de observación. Esto último se echa de ver en el verismo de sus ambientes y de sus personajes, que están - ambos - minuciosamente descritos. Los seres que pueblan la pensión a la que Rosaura llega una noche a las diez, están logrados más que nada por su peculiar manera de expresarse y por la interpretación que hacen de Rosaura, del crimen, de los móviles del supuesto asesino y de una serie de acontecimientos que han tenido lugar frente a ellos o de los que participaron.

El ingenio está ampliamente demostrado en la estructura del libro: cuatro partes más un epílogo en forma de carta que constituyen otros tantos puntos de vista diferentes, y que giran alrededor de un mismo hecho y de una misma persona. Es decir, la misma técnica de la película

$838^{4}$ ed. Buenos Aires: Kraft, 1961, Deveni ha escrito asimismo teatro, fábulas breves y una colección de cuentos. 
Rashomon: el protagonista dialoga con la policía, otros dos personajes natran en forma muy personal los acontecimientos y, en un caso, el autor es el vocero de lo que uno de los testigos ha declarado. Por último, una carta de Rosaura devela todos los misterios. Es un perfecto rompecabezas en que el suspenso está matemáticamente administrado y medido y en el que poco a poco se nos dan indicios que, nosotros los lectores, debemos ordenar en función de la verdad final. $Y$ esa participación vital que se nos demanda es la que, por decir así, nos agarra a las páginas de Denevi.

Junto a esa atmósfera policial hay en Rosaura a las diez hondura sicológica. Camilo Canegato-el protagonista- es un hombrecillo gris, frustrado, lleno de temores, que se inventa una mujer para poder soportar una existencia anodina. La solterona Eufrasia, la dueña de la pensión, Rosaura, David, son otros tantos seres de carne $y$ hueso a cuyo interior ha llegado Denevi con mordacidad y penetración. Hay, asimismo, un juguetón humorismo, una ironía que roza diversos temas. Hay todo un pequeño cosmos dentro de las paredes de "La Madrileña", y cada ser allí lleva a cuestas su propia cruz, su miseria única que se revela cuando todos se lanzan sobre la tragedia de Camilo, al fin y a la postre, más feliz que todos ellos porque tiene su refugio.

Los tallos amargos $5^{84}$ de Adolfo Jasca es una interesantísima novela policial y sicológica, con un original tratamiento en el que radica su mayor valor. Está dividida en dos partes - "Requiem para un lituano" y "Requiem para un asesino". En la primera se presentan los personajes y el crimen; en la segunda se dan los hechos que conducirán al desenlace inesperado. Pero las dos partes no están escritas en la misma forma: "Requiem para un lituano" se desarrolla en dos planos que pueden leerse separadamente y que constituyen otras tantas "nouvelles". Un plano, destacado en cursiva, constituye el relato del crimen y en un segundo plano -en redondilla - se desciende al interior del protagonista, de su carácter, de su vida, de su trabajo, de su amistad con la víctima. Todo esto, a su vez, en perspectiva temporal presente y pasada y con cantidad de sueños que permiten al autor trazar la semblanza anímica completa de su protagonista. Así, éste emerge, muy claramente, como iluso, débil, inseguro de sí mismo, con una personalidad paranoica que explica de manera lógica su crimen, en virtud del cual él se transforma - a sus propios ojos- en un héroe, pues ha vengado la burla de que lo hacía víctima su amigo. Mas toda esa recién adquirida seguridad y confianza del criminal, se viene abajo cuando se le revela la inutilidad, la injustificación

$842^{*}$ ed. Bucnos Aires: Emecé, 1965. Ha sido filmada con el mismo título. 
de su crimen. $Y$ esto es lo fundamental en el libro: mostrar cómo ambos hombres mueren víctimas uno, de su propia enferma personalidad y el otro, por su sed de triunfo y su excesiva confianza en sí mismo. Estos planos de la primera parte no se "denuncian" entre sí sino que se complementan perfectamente y llegan a un punto en que se unen, desapareciendo entonces la diferencia de tipografía.

La figura del criminal Gasper, su frustración y sus ansiedades, su paranoia están muy bien entregadas. Es el personaje más nítidamente construido. De su víctima, el lector llega a conocer su verdadera naturaleza, sólo a través de los datos que aporta un tercer personaje. Tal como lo vemos directamente, nos desconcierta, pero ello ha sido buscado por el autor porque, de otro modo, se hubiera destruido el efecto que produce en el lector el descubrir la inutilidad del crimen.

\section{CONCLUSIONES}

Aun con ser muy breve y esquemática nuestra incursión en la novelística argentina de los últimos quince años, ella nos permite añadir algunas consideraciones finales. En lo que respecta a lo exclusivamente literario, podemos hablar de novelas de tono pesimista, triste, de ambientes y personajes sórdidos. El sexo es una constante temática de esta narrativa, pero una constante violenta, obsesiva, retorcida. Un sexo agresivo y brutal que no lleva a la comunicación entre los seres sino tan sólo a la animalidad del desahogo fisiológico. La soledad es otro de los temas repetidos, una soledad impuesta por la ideología, por la sociedad o por dubitaciones metafísicas. La alteración de la secuencia cronológica de los hechos, o el uso de un tiempo subjetivo es común a todas estas novelas, como así también el uso - y el abuso- de todas las técnicas narrativas modernas. Pero si en novelas como las de la tierra estas nuevas técnicas agregan una riqueza de que la tradicional novela telúrica hispanoamericana carecía, en general no puede decirse lo mismo. Se abusa de la complejidad estructural $y$, frecuentemente, el tema no justifica la intrincada maraña de técnicas y procedimien os ante los que el lector avanza penosamente. En muchos de estos jóvenes parecería haber más que una honesta preocupación formal, una superflua ostentación de lecturas o una infantil necesidad de mostrar madurez a fuerza de complejidad. Semejante reserva hay que hacer acerca del uso de variadas formas de relieve expresivo por medio de la tipografía, como lo hemos indicado en cada caso. Pero quizá nuestro mayor desasosiego se da con respecto a la lengua de alguno de 
estos escritores $o$, con más exactitud, a sus incorrecciones de sintaxis, al descuido con que escriben. Comprendemos que en la actualidad no ya el escritor sino el público busca en la novela acusación, protesta, testimonio, información. Comprendemos que si la denuncia o el testimonio han de ser verdaderos, deberán ser fiel reflejo de la realidad, del contorno, para hablar con palabra acuñada por estos escritores. Pero de la lectura de esta novelística no se deriva placer estético alguno, no hay destreza en el manejo de la lengua o un sólido conocimiento de ella. Hay que escribir, eso es todo; hay que hacerlo de alguna manera. $Y$ esta subordinación exagerada del cómo al qué implica excesos que conducen directamente a la trivialidad cuando no a la barbarie. La novela es arte, mas no en estos escritores. En ellos parecería haberse igualado novelar con periodismo, y esto con grave desmedro para aquel género literario.

En otro orden de ideas, el recorrido que hemos hecho nos habla del predominio del ambiente urbano sobre el rural, y cuando - en la Argentina- se habla de lo urbano eso significa Buenos Aires. La gran ciudad aparece en la mayoría de estos escritores. Se nombran sus calles, sus plazas, se hace referencia a alguna de sus peculiaridades. Pero no se la caracteriza a fondo. Buenos Aires es más bien la compañera fiel y callada de los errantes itinerarios a que se entregan estos perscnajes en sus crisis. Buenos Aires está allí como presencia real y constante un poco al modo en que lo estả Milán en "La notte" o Londres en "Blow up".

$\mathrm{Y}$ una última observación. El número de novelistas (como el de poetas y cuentistas) crece y se multiplica en la Argentina en forma infinita: todo "el que es" (o quiere ser), es escritor. Las editoriales argentinas, por fin, han descubierto que hay un público para los autores nacionales (o que lo pueden crear). Los premios que ellas confieren, como así también los de la SADE o el apoyo del Fondo Nacional de las Artes, todo ha contribuido a la mayor difusión del libro argentino dentro del país. Pero esta misma euforia de la consagración nacional es quizá la fuente de actitudes irresponsables y frívolas por parte de algunos autores que prefieren un éxito fácil basado en la crónica escandalosa o en la avidez sensacionalista del público a la tarea lenta y exigente de una obra seria cuya consagración dependerá, exclusivamente, de los méritos literarios. Por ello el número, el gran número de los novelistas actuales en la Argentina, configura una enorme llanura, una "pampa" de nombres de autores y libros, una uniforme superficie de valores semejantes en la que no se eleva una sola cumbre. La novela argentina producida por estos jóvenes es buena novela, aceptable, de valores desiguales, con aciertos y 
faltas pero no es la gran novela argentina ni mucho menos continental. No obstante esta nivelación en medianía - una medianía distinguida, sin embargo-, hay que convenir en que la novelística argentina se expresa hoy con un énfasis, una agresividad y una confianza totales. La Argentina se busca con lucidez y con preocupado ademán y la literatura de estos jóvenes es de definición, como lo ha sido siempre en la historia de las crisis institucionales argentinas, como lo fue durante Rosas y en el $80 \mathrm{y}$ en el 30. Y lo que "los enojados" están haciendo -aun con todas sus limitaciones- tiene un valor: el de contribuir a esa auscultación del país para obtener un diagnóstico, despertar al paciente y obligarlo a su cura.

New York, abril de 1967.

Angela B. Dellepiane

City College.

City University of New York. 